\title{
Chemical characteristics of water masses in the Rockall Trough
}

Triona McGrath; Glenn Nolan, Evin McGovern

Corresponding Author: Ms Triona McGrath, Corresponding Author's Institution: Marine Institute

\begin{abstract}
Direct observations of physical and chemical data in the Rockall Trough during February of 2008, 2009 and 2010 are presented. Results are compared to a similar WOCE transect, AR24, completed in November/December 1996. Temperature and salinity data have been used to identify the water masses present in the Trough, and have been combined with nutrient (nitrate, nitrite, phosphate, silicate) and oxygen data to produce a table outlining the chemical characteristics of each of the water masses. Eastern North Atlantic Water (ENAW) moving north through the Trough gains nutrients from a branch of the North Atlantic Current (NAC). Mediterranean Water (MW) was identified as a warm saline core, with characteristically low oxygen and low preformed nutrients along the Irish continental shelf break near $53^{\circ} \mathrm{N}$. Found at a similar density level at the southern entrance to the Trough, Sub Arctic Intermediate Water (SAIW) has relatively high oxygen and preformed nutrients, likely entrained from the subpolar gyre when it was formed. LSW was identified as a prominent water mass between 1500-2000m deep, with characteristically high oxygen content. Lower silicate, and to a lesser extent preformed nitrate, in 2009 coincide with a freshening of Labrador Sea Water (LSW) relative to other years, and could indicate a stronger influence from the Labrador Current when it was formed. Finally, traces of Antarctic Bottom Water (AABW) were found as far north as $53^{\circ} \mathrm{N}$, indicated by a sharp increase in nutrient concentrations, particularly silicate in the deepest parts of the Trough.
\end{abstract}

Keywords: water masses; nutrients; oxygen; salinity; Rockall Trough; North Atlantic 


\section{Introduction}

The Rockall Trough is a deep sea channel, west of the Irish continental shelf, bounded to the west by the Rockall Bank (Figure 1). The southern entrance to the Trough is over $3000 \mathrm{~m}$ deep, and it is connected to Nordic Seas by the shallow (500m) WyvilleThomson Ridge in the north. To the west of the Rockall Trough lies the boundary between the two counter-rotating gyres, the subpolar and subtropical gyres of the North Atlantic. The North Atlantic Current (NAC) is an extension of the Gulf Stream that carries warm, salty water eastwards across the North Atlantic. Upon reaching the Rockall Plateau, one branch circulates northwest towards Iceland, while the other circulates through the Rockall Trough before reaching the Norwegian Sea (Ellett and Martin, 1973; Pollard et al., 1996). This region is therefore an important part of the ocean-climate system, as it provides a pathway for warm and saline water of the upper North Atlantic to enter the Nordic Seas, where it is converted into cold, dense overflow water as part of the warm-to-cold water transformation of the thermohaline circulation (Ellet \& Martin, 1973; Holliday et al., 2000). Although the different water masses found in the Rockall Trough have been well documented (Johnson et al., 2010; New and Smythe-Wright, 2001; Read, 2001; Ullgren and White, 2010), the chemical make up of these water bodies is less well understood. Some of the water masses in the region have overlapping temperature-salinity properties, and so the chemical characteristics of each are examined here to help identify the water masses present.

Biogeochemical and physical processes determine the nutrient and oxygen distribution in the world's oceans. Although the ageing of a water mass results in a 
decrease in oxygen and increase in dissolved inorganic nutrients (due to respiration), vertical profiles broadly reflect water masses as defined by temperature and salinity, highlighting the important role of physical transport (Williams and Follows, 2003). Despite their non-conservative properties, chemical tracers like nutrients and oxygen can help us to more accurately define water masses and can indicate processes that have occurred along their path. They can also be combined in such a way as to make them conservative as their concentrations change in fixed proportions within the water mass.

Oxygen content in seawater is controlled by direct fluxes from the atmosphere when the water mass is formed, and by respiration and photosynthesis. The flux of atmospheric oxygen into seawater is temperature dependent, with colder water absorbing more oxygen than warm water. Apparent oxygen utilisation (AOU) is the oxygen saturation value minus the oxygen measured (Broecker and Peng, 1982). Positive AOU values are indicative of respiration in the water column, or in surface waters it could indicate upwelling or convection, with subsequent mixing of deeper oxygen-depleted water with surface water saturated with oxygen. Natural sources of nutrients to the open ocean are from atmospheric deposition, nitrogen fixation, land erosion and volcanic activity, while anthropogenic inputs from agriculture, industry and fossil fuel consumption may also reach the open ocean via rivers, rainfall and the atmosphere. Biological drawdown of nutrients through photosynthesis, remineralisation of organic material and physical mixing, largely determine the vertical profile of nutrients in the ocean (Williams and Follows, 2003). Due to the ageing of a water mass, it is not always possible to determine whether an increase of nutrients at a particular depth is due to remineralisation of organic matter or physical 
mixing with another water mass. We have therefore looked at both nutrient and preformed nutrient concentrations, to help identify the water masses present. Preformed nutrients are the sum of the total nutrients minus regenerated nutrients in a water mass, assuming that upon formation the oxygen concentration was in equilibrium with the atmosphere (Broecker and Peng, 1982). They are the nutrient concentrations initially present in seawater at the time of downwelling, before any remineralisation has occurred and are therefore characteristic of waters originating in different regions.

\subsection{Water masses in the Rockall Trough}

Much of the upper $1000 \mathrm{~m}$ in the northeast Atlantic is dominated by Eastern North Atlantic Water (ENAW), a water mass having salinities lying within \pm 0.05 of a mixing line from $\theta$ (potential temperature) of $12^{\circ} \mathrm{C}$ and salinity of 35.66 , to $\theta$ of less than $4^{\circ} \mathrm{C}$ and salinity $<34.96$ (Harvey, 1982), with a small inflection point at $10^{\circ} \mathrm{C}$, salinity of 35.40. As ENAW travels north from its formation region in the Bay of Biscay (Pollard et al., 1996), it is progressively freshened by mixing with water masses moving in from the west (Ellett et al., 1986). Subarctic Intermediate Water (SAIW) is a highly stratified water mass, with temperatures between $4-7^{\circ} \mathrm{C}$ and salinity $<34.9$ in its formation region in the western boundary current of the subpolar gyre, in the Labrador Current (Harvey and Arhan, 1988). This cold, fresh water mass subducts and spreads westwards with a branch of the NAC to the southern entrance of the Rockall Trough (Arhan, 1990; Arhan et al., 1994), see Figure 2. Ullgren and White (2010) identified SAIW in the Rockall Trough between 600-1000m, with salinities of 35.1-35.2 and temperatures of $8-9^{\circ} \mathrm{C}$. 
Found at a similar depth to SAIW at the southern entrance to the Rockall Trough, Mediterranean Water (MW) is a highly saline outflow from the Mediterranean Sea through the Straits of Gibraltar. Although MW has a temperature $>11.5^{\circ} \mathrm{C}$ and salinity of 36.5 in the source region (Pérez et al., 1993; Tomczak and Godfrey, 1994), by the time it reaches the Rockall Trough these properties have been diluted due to lateral mixing with adjacent water masses and it is normally seen as an inflexion in the $\theta-S$ (potential temperature-salinity) plots in the Rockall Channel (Ellett and Martin, 1973). While earlier studies suggested the MW core continued through the northern end of the Rockall Channel (Reid, 1979), recent studies have found that the warm waters of the NAC set the inflow characteristics to the Nordic Seas and MW is only a dilute constituent of the inflow, but indirectly through its contribution to the interior subtropical gyre, from which the NAC draws its water (McCartney and Mauritzen, 2001; New et al., 2001).

Wyville-Thomson Overflow Water (WTOW), a southward-flowing overflow water from the Nordic Seas, is found at intermediate depths in the northern Rockall Channel and is also seen as an inflexion towards higher salinity in $\theta-\mathrm{S}$ diagrams (Sherwin et al., 2008). It has only recently been placed as an intermediate water mass found as far south as $55^{\circ} \mathrm{N}$ in the Trough, with $\theta-\mathrm{S}$ properties along a mixing line of $0.5-8^{\circ} \mathrm{C}$ and 34.85-35.25 (Johnson et al., 2010).

Labrador Sea Water (LSW) is formed from deep winter convection in the Labrador Basin and $\theta-S$ properties of LSW can vary between years depending on local climate factors that influence the convection regimes in the Labrador Sea. Yashayaev (2007) 
reported potential temperatures $(\theta)<2.8^{\circ} \mathrm{C}$ and salinities $<34.84$ in LSW during an extremely cold and fresh phase in 1994 , while $\theta$ was $2.9-3.1^{\circ} \mathrm{C}$ and salinity 34.88 34.90 during a warmer, saltier state in 2005 . It has been clearly identified in the Rockall Trough between 1600-1900m (Ellett et al., 1986; Ellett and Martin, 1973). LSW is a relatively young water mass in the Trough, and has a transit time from the Labrador Sea to Rockall Trough of ca. 10 years (Yashayaev et al., 2007).

Iceland-Scotland Overflow Water (ISOW) has salinity values $>34.98$ and potential temperature $<3^{\circ} \mathrm{C}$ (Harvey, 1982). It is formed in the northern Iceland Basin and characteristics of this water mass are significantly altered due to diapycnal mixing when it travels south (van Aken, 2000a). In the Rockall Trough, it is strongly modified by mixing with ENAW, and creates a deep salinity maximum about 1800 2000m found on the western side of the Rockall Channel (Castro et al., 1998).

Northeast Atlantic Deep Water (NEADW) is seen as a salinity maximum between the fresh LSW above it and LDW (Lower Deep Water) and/or AABW (Antarctic Bottom Water) below it (Ellett and Martin, 1973). The upper limit of NEADW has a temperature and salinity of $2.5^{\circ} \mathrm{C}$ and 34.94 respectively, and a lower limit of $2.03^{\circ} \mathrm{C}$ and 34.89, and represents one of the largest water mass volumes of the European Basin (Worthington et al., 1970). AABW is formed by deep convection associated with the freezing of sea ice in the Weddell and Ross Seas, and after mixing with the waters of the Circumpolar Current, it has a potential temperature of $\sim 0.3^{\circ} \mathrm{C}$ and salinity of 34.7 (Tomczak and Godfrey, 1994). AABW flows north, along the eastern side of the northeast Atlantic, and mixes up into NEADW, which then circulates into 
the Rockall Trough (Ellett and Martin, 1973; McCartney, 1992; New and SmytheWright, 2001; Tsuchiya et al., 1992).

Figure 2 illustrates the position of the major water masses across the region extending from the Irish shelf about $52^{\circ} \mathrm{N}$ across the Rockall Trough. Salinity data was taken from a National Seabed Survey in 2010. Table 1 summarizes the hydrographic characteristics of the above water masses in the northeast Atlantic.

\section{Method}

The main data sets presented here were collected during three surveys to the Rockall Trough (Fig. 3); two on the RV Celtic Explorer in February 2009 (CE0903) and 2010 (CE10002), and one on the $R V$ Thalassa in February 2008 (TH08). Data from a similar survey, WOCE-AR24 completed in November/December 1996 has also been examined to identify any differences over a longer timescale. WOCE AR24 data was extracted from the CDIAC database (https://cdiac.ornl.gov/oceans/).

\subsection{CTD data}

On all recent cruises a Seabird SBE 9/11 CTD rosette system was employed. Temperature calibration for the Seabird CTD was carried out using an independent Seabird SBE-35 electronic digital thermometer while salinity was calibrated by analysing discrete water samples on a Guildline Portasal salinometer (Model 8410A). An SB43 oxygen sensor was deployed with the CTD, which was calibrated annually with the manufacturer. 


\subsection{Sample Collection}

Seawater samples were collected in Niskin bottles for the analysis of dissolved oxygen $\left(\mathrm{O}_{2}\right)$, dissolved nutrients (silicate $(\mathrm{Si})$, total oxidised nitrogen $(\mathrm{TOxN})$, phosphate $\left(\mathrm{PO}_{4}\right)$, nitrite $\left.\left(\mathrm{NO}_{2}^{-}\right)\right)$and salinity. The natural level of $\mathrm{NO}_{2}^{-}$in seawater is very low, since in the presence of oxygen, $\mathrm{NO}_{2}^{-}$should be oxidised to $\mathrm{NO}_{3}$. (Grasshoff et al., 1983). $\mathrm{NO}_{2}^{-}$results were generally below the limit of quantification $(<0.04 \mu \mathrm{mol} \mathrm{kg}-1)$, therefore TOxN and nitrate $\left(\mathrm{NO}_{3}\right)$ can be considered equivalent. $\mathrm{NO}_{2}$ data is therefore not included here. $\mathrm{O}_{2}$ samples, collected in 2010 only, were analysed on board ship following the Winkler method (Winkler, 1988), modified with potentiometric endpoint determination. A Metrohm 848 Titrino Plus was used for $\mathrm{O}_{2}$ analysis, with a Metrohm combined Pt electrode; precision is estimated to be $\pm 1.45 \mu \mathrm{mol} \mathrm{kg}{ }^{-1}$. There was a constant offset of $\sim 15 \mu \mathrm{mol} \mathrm{kg}{ }^{-1}$ between the oxygen sensor data and Winkler results in 2010; sensor data was corrected for this offset. See supplementary information.

The apparent oxygen utilization (AOU) (Broecker and Peng, 1982) was calculated as

$\mathrm{AOU}=\mathrm{O}_{2}$ sat $-\mathrm{O}_{2}$ observed

and assumes that seawater downwelling from the surface is $100 \%$ saturated with respect to the atmosphere. Discrete oxygen samples were only collected in 2010, and the resulting AOU in the surface mixed layer was $7.67 \mu \mathrm{mol} \mathrm{kg} \mathrm{kg}^{-1}$ (i.e. $97 \%$ saturated). While 2008 oxygen sensor data gave similar values (98\% saturated in the surface mixed layer), there appeared to be an offset of $\sim 28 \mu \mathrm{mol} \mathrm{kg}^{-1}$ in the 2009 oxygen sensor data (see supplementary information). While other studies have adopted an air saturation of $98 \%$ as a best estimate for late winter in the northeast Atlantic (Koeve, 
2001; Körtzinger et al., 2001), the 2009 oxygen sensor data was re-calculated based on the assumption that the surface mixed layer is approximately $97 \%$ saturated each winter, since the Winkler data from 1996 and 2010, which are more accurate than sensor data, resulted in 97\% saturation in the surface mixed layer in the Trough.

For the above calculations of AOU, and also for preformed nutrients in the following section, it is assumed that upon formation a water mass is $100 \%$ saturated with oxygen with respect to the atmosphere. There may be times however, when this assumption is questionable, particularly with any water mass formed by convection. Surface cooling results in the rapid sinking of surface water in a convection cell, which is replaced by water that rises to the surface on the perimeter of the cell, mixing partially with the water in the core. The resulting water mass may therefore be undersaturated with respect to the atmosphere and its oxygen concentration is determined by the oxygen content of the sinking water, which is saturated in oxygen, and by the oxygen content of the rising water, which mixes with it (Tomczak, 1999) . This is particularly the case for LSW, where saturation levels between $60 \%$ and $100 \%$ have been reported in the Labrador Sea, with significant horizontal and vertical variability (Azetsu-Scott et al., 2005; Wallace and Lazier, 1988). Therefore, both AOU and preformed nutrients have been calculated for a range of saturation states between $60-100 \%$ for this water mass. On the other hand, the saturation state of a subducted water mass, e.g. SAIW, is generally saturated with oxygen due to the slow downward motion of the surface water (Tomczak, 1999). To ensure this is true for SAIW, AOU and preformed nutrients were therefore also calculated for a range of initial saturation levels. 
Samples for dissolved nutrients were filtered through acid-cleaned $0.45 \mu \mathrm{M}$ polycarbonate filters and filtration units, and frozen on board in $50 \mathrm{ml}$ falcon tubes. The nutrients were analysed with a Skalar $\mathrm{San}^{++}$continuous flow analyser at the Marine Institute by standard colorimetric methods (Skalar methods M461-031e for TOxN, M467-033 for $\mathrm{NO}_{2}, \mathrm{M} 503-010$ wlr for $\mathrm{PO}_{4}$ and M563-051 for Si). The Marine Institute routinely participates in QUASIMEME proficiency testing scheme exercises for nutrients and salinity in the marine environment. Results from 7 QUASIMEME rounds (42 samples) between July 2008 and May 2011 gave an average z-score of $\leq 0.5$ for all parameters, putting confidence in the nutrient and salinity data. It is very clear from Fig. $6 \mathrm{~b}$ that the $\mathrm{TH} 08$ (2008) $\mathrm{PO}_{4}$ is lower from below $1000 \mathrm{~m}$ to the deepest part of the Trough. This has not been explained but all the CRMs and calibration curves were checked, and there does not appear to be a problem with the analysis.

WOCE AR24 $\mathrm{O}_{2}$ samples were also determined with a modified Winkler technique using a Metrohm Model 665 Dosimat Buret and PC controller. Aliquots of the prepared sample were titrated similar to Strickland and Parsons (1972) and the endpoint was determined amperometrically using a dual plate electrode. Nutrient samples were collected in acid-cleaned HDPE bottles, and were refrigerated and analysed on an ODF-modified 4-channel Technicon Auto Analyser II within 4 hours of sampling.

Preformed nutrients are calculated by combining $\mathrm{O}_{2}$ and $\mathrm{NO}_{3}$ or $\mathrm{O}_{2}$ and $\mathrm{PO}_{4}$ in such a way that respiration can be cancelled; 
$\mathrm{NO}_{3}{ }^{\circ}=\mathrm{NO}_{3}-\mathrm{AOU} / a$

$\mathrm{PO}_{4}{ }^{\circ}=\mathrm{PO}_{4}-\mathrm{AOU} / b$

where $a$ and $b$ are equivalence factors between moles of oxygen consumed and nitrate/phosphate released by oxidation of organic material (Broecker and Peng, 1982). Here we have used stoichiometric ratios of $a=10$ and $b=163$, calculated for the northeast Atlantic and European margins by Perez et al. (1993). There is no accepted stoichiometric ratio for silica with oxygen because the dissolution of biogenic silica in diatom frustules occurs differently than remineralisation of organic material (Pérez et al., 1993). Figure 7e clearly illustrates the conservative nature of preformed nutrients with salinity, with a straight mixing line between the relatively low-nutrient ENAW, and a mixture of LSW, NEADW and AABW. While $\mathrm{PO}_{4}{ }^{\circ}$ is not shown here, the profile is very similar to that of $\mathrm{NO}_{3}{ }^{\circ}$. This supports the idea that the distribution of preformed nutrients is largely determined by physical mixing and the water masses present.

The innovative aspect of this paper is Table 2, outlining the chemical characteristics of regional water masses after entering the Rockall Trough. Water masses were first identified using temperature and salinity data, then the average of the chemical parameters within each water mass were calculated to produce the table of results (Table 2).

\section{Results}

In order to identify the different water masses present in the Rockall Trough during the winter months of 1996, 2008, 2009 and 2010, we first examine and compare the $\theta$ - 
S (potential temperature-salinity) profiles of the southern (Fig. 4a) and northern (Fig. 4b) transects of the Trough. We then combine the nutrient and oxygen results with the physical data to determine the chemical make up of each of the water masses present, and note the significant differences, if any, between each year.

\subsection{Physics}

In the upper $1000 \mathrm{~m}$, there is a clear signal of the warm and salty ENAW for all years, across both transects. There is much more variability in water properties in the upper $1000 \mathrm{~m}$ of the southern transects (Fig. 4a) relative to the northern transects (Fig 4b). Between $500-1000 \mathrm{~m}$ in the southern transects, on the eastern side of the section the $\theta$ S tend towards MW, while on the western side of the Trough, tend towards SAIW. The SAIW is most prominent in 2010, see fig. 4a (iv). MW and SAIW signatures are not present in the northern transects, where properties in the upper $1000 \mathrm{~m}$ appear more uniform (Fig 4b). There is a slight inflexion towards higher salinity in the $\theta-S$ profile in the northern transect of 2009 and 2010 close to the WTOW mixing line about 1000m (Fig. 4b (ii)). While the salinity inflexion falls slightly above the WTOW line as described by Johnson et al. (2010), that line is based on measurements along a transect north of $57^{\circ} \mathrm{N}$ in the Trough so the salinity may have increased due to mixing with the more saline ENAW. There is no WTOW inflexion apparent in the 1996 data (Fig. 4b (i)), with a straight mixing line between ENAW and LSW. Below these intermediate water masses, $\theta$-S profiles join together outlining a clear LSW signal in both transects. LSW has been observed to freshen in this region between 2006 and 2009 with a return to higher salinities observed in 2010 (Nolan, in prep). LDW or AABW are found in the deepest parts of the Trough. 
The average oxygen concentration in the surface mixed layer $(\sim 300 \mathrm{~m})$ across both transects in 2010 is $261 \mu \mathrm{mol} \mathrm{kg}{ }^{-1}$, with AOU values close to $8 \mu \mathrm{mol} \mathrm{kg}$, i.e. surface waters are 97\% saturated (Fig. 5). The surface mixed layer of both transects in 1996 was similarly $97 \%$ saturated, also calculated using $\mathrm{O}_{2}$ Winkler data. Below the winter mixed layer, oxygen concentrations decrease rapidly coinciding with a large increase in AOU. This low oxygen and high AOU zone closely mirrors the base of the winter mixed layer as seen in the temperature and salinity contours, and is seen slightly deeper in the northern transect (Fig. 5). Although this low oxygen zone extends across the Trough, concentrations are lowest between 700-1000m along the continental shelf of the southern transect, for example in 2010 oxygen values average $203 \mu \mathrm{mol} \mathrm{kg}{ }^{-1}$ between 700-800m (AOU 76 $\mu \mathrm{mol} \mathrm{kg}{ }^{-1}, 73 \%$ saturated). Between 1500 and $2000 \mathrm{~m}$, the oxygen concentration markedly increases, to concentrations the same as or above surface concentrations, and AOU is approximately $40 \mu \mathrm{mol} \mathrm{kg}{ }^{-1}(86 \%$ saturated). Below this oxygen rich layer, the dissolved oxygen gradually decreases with depth

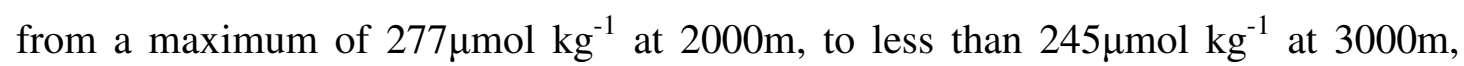
while AOU concentrations increase to almost $85 \mu \mathrm{mol} \mathrm{kg}{ }^{-1}$ in the deepest part of Trough (74\% saturated). Oxygen concentrations and AOU for the northern and southern sections in 2010 are plotted in Figure 5. Similar section profiles were also seen in the oxygen sensor data of 2008 and 2009.

\subsection{Nutrients}

Nutrients in the Trough are low in surface waters (SW) each year, with a sharp increase in concentrations below the winter mixed layer, coinciding with the increase 
in $\mathrm{AOU}$ (Fig. 6). The increase in $\mathrm{Si}$ is less pronounced that of $\mathrm{NO}_{3}$ and $\mathrm{PO}_{4} \cdot \mathrm{NO}_{3}$ in surface waters of AR24 (1996) is lower than recent years, and coincides with a shallower surface mixed layer $(\sim 150 \mathrm{~m})$. The average NP ratio in the 1996 data is also much lower (13.7) in the surface mixed layer than the average over 2008-2010 ( 17). Between 1500-2000m there is a slight decrease in $\mathrm{NO}_{3}$ and $\mathrm{PO}_{4}$, with little change in Si concentrations. Below $2000 \mathrm{~m}$ there is a steady increase in all nutrients down to the deepest parts of the Trough, particularly seen in the Si profiles.

\subsection{Spatial Distribution}

In 2008 and 2009, stations at the western end of the southern transect have lower surface $(<300 \mathrm{~m})$ temperatures and salinities than stations along the eastern side of the Trough (see Fig. 8, temperature not shown here). This colder, fresher surface water has higher concentrations of nutrients than the water near the shelf edge (see results in Table 2a and Fig. 7). This pattern is not as obvious in 1996 and 2010, where surface waters appear slightly more mixed across the channel.

Section plots of the southern transect of 1996, 2008 and 2009 indicate water below the winter mixed layer at the western side of the Trough has lower salinity and temperature relative to water towards the continental shelf (Fig. 8). In 2010, this cooler, fresher water is seen in the middle of the Trough (stations 64-66). This pattern is seen in all years down to below 1000m (Fig. 8). Between 500-600m, the colder, fresher water has lower oxygen, and higher nutrients and AOU than surrounding water at the same depth. Although the preformed nutrients are also relatively high in 
this water, the higher AOU suggests remineralisation has also contributed to the elevated nutrients seen at these stations.

Between 700 and $1000 \mathrm{~m}$, the colder, fresher waters found at western-most stations in 2008 and 2009 and in the centre of the Trough in 2010, have average temperature and salinity values of $6.02^{\circ} \mathrm{C}$ and 35.11 over the three years, typical of SAIW in the Rockall Trough (Ullgren and White, 2010). This is supported by the $\theta$-S diagrams, which illustrate that some data points from the southern transect tend towards SAIW properties (Fig 4a). SAIW is also clearly identified in 1996 with average salinity and temperature of 35.08 and $5.83^{\circ} \mathrm{C}$, at stations $144-148$ at the western end of the transect. AOU and preformed nutrients were calculated for a range of initial saturation states and results indicated that the SAIW measured in the Trough in 2008, 2009 and 2010 was between $85-100 \%$ saturated when it was formed, while the SAIW that was measured in the Trough in 1996 was initially 80-100\% saturated. Any initial saturation level below these values resulted in SAIW having positive AOU values and preformed nutrients higher than the actual nutrient concentrations measured in the Trough. This could not be the case since SAIW has been away from the surface for a number of years, therefore oxygen levels should gradually decrease. In any year, an initial saturation of $80 \%$ when SAIW was formed yields lower AOU and higher preformed nutrients than an initial saturation of $100 \%$ (see Table 2a). Therefore, in all years, regardless of the initial saturation value used between $80-100 \%$, SAIW measured in the Trough has higher nutrients and calculated preformed nutrients than surrounding water, along with higher oxygen concentrations and relatively lower levels of AOU. This suggests that remineralisation does not contribute to the elevated nutrient levels, and that source water properties are higher in oxygen and nutrients 
than surrounding water masses (Table 2a). Figure 7e clearly illustrates that between 500-1000m, water with salinity between 35.1-35.2 has higher preformed nutrients than the same depth further east in the Trough.

In all years, apart from surface waters, highest salinity and temperature are found at stations closest to the shelf between 700-1000m deep at the southern transect (Fig. 8). The width of this warm, saline core varies between years; in 2008 and 2010 it was confined to 1 or 2 stations on the shelf edge ( $\sim 30 \mathrm{~km}$ from shelf edge), while in 1996 and 2009 this core spread further out to $\sim 130 \mathrm{~km}$ from shelf break. Lowest oxygen values measured in the Trough were also measured in this warm, saline core. Temperature, salinity and $\mathrm{O}_{2}$ concentrations average $35.35,9.23^{\circ} \mathrm{C}$ and $204 \mu \mathrm{mol} \mathrm{kg}{ }^{-1}$, respectively, in this core over 2008, 2009 and 2010; indicative of MW in the southern Rockall Trough region. While $\mathrm{NO}_{3}$ and $\mathrm{PO}_{4}$ concentrations are similar at these stations to surrounding water at that depth, preformed nutrients are lower, suggesting source water has lower nutrient concentrations. The $\mathrm{N}^{\circ}: \mathrm{P}^{\circ}$ ratio (preformed NP ratio) is however higher here than water further west in the Trough, reaching 19 at station $70(900 \mathrm{~m})$ and $71(720 \mathrm{~m})$ in 2010,18 at station $12(1000 \mathrm{~m})$ in 2009 and 17.5 at stations 7-9 (700m) in 2008, suggesting source water has a high NP ratio. This high NP signal was however not measured at all depths within this water mass each year, and was not measured in the 1996 data. Si concentrations at these stations are lower than similar depths across the rest of the Trough (Table 2a). In 1996, highest salinities and temperatures were also found at the stations closest to the shelf (station 134-140) at $\sim 900 \mathrm{~m}$. Low oxygen $\left(205 \mu \mathrm{mol} \mathrm{kg} \mathrm{kg}^{-1}\right)$ and high AOU $\left(75.6 \mu \mathrm{mol} \mathrm{kg} \mathrm{kg}^{-1}\right)$ values were also measured here, along with lower preformed nutrients than stations further west in the Trough. 
The top 1000m of the northern transects in 1996, 2009 and 2010 are somewhat similar to that seen further south, however there is little east-west gradient in water properties across the Trough (Fig. 8). The decrease in oxygen and increase in nutrients also occurs slightly deeper in the water column than the southern transects, and SAIW and MW signals are absent in the northern transects each year.

$\theta$-S diagrams of the 2009 and 2010 northern transects indicate the presence of WTOW between 800 and $1100 \mathrm{~m}$ at stations close to the Rockall Bank. Like MW in the southern transect, WTOW is seen as an inflexion in the $\theta-\mathrm{S}$ diagrams (see Fig $4 \mathrm{~b}$ ). However, oxygen is much higher in WTOW than in MW, agreeing with Johnson et al. (2010) that the salinity inflexion is not a continuation of the MW signal. In relation to the rest of the northern transect at that depth, oxygen and nutrient concentrations do not appear significantly different than surrounding water; however there are very few data points to accurately determine the chemical characteristics of this water mass in the region. There does not appear to be any clear WTOW signature in the northern transect of the 1996 AR24 survey.

Unlike the water depths above it, there is no east-west gradient in temperature, salinity, oxygen or nutrients across the transects between 1500-2000m deep. The average salinity, temperature and oxygen over 2008, 2009 and 2010 was 34.92, $3.72^{\circ} \mathrm{C}$ and $278 \mu \mathrm{mol} \mathrm{kg}{ }^{-1}$, respectively. The low salinity and temperature, and high oxygen values measured between $1500-2000 \mathrm{~m}$ are typical of LSW properties in the Rockall Channel (Stoll et al., 1996). The temperature and salinity of this water mass is marginally higher in the northern transect in 1996, 2009 and 2010. As mentioned 
previously, between $60-100 \%$ saturation states have been reported in the Labrador Sea (Azetsu-Scott et al., 2005). AOU and preformed nutrients were therefore calculated for $\mathrm{LSW}$ at $60 \%, 70 \%, 80 \%, 85 \%, 90 \%$ and $100 \%$ saturation states. For all years, AOU calculated at any initial saturation less than $85 \%$, indicated that LSW in the Rockall Trough was supersaturated with oxygen, and preformed nutrient values were higher than the actual nutrient concentrations measured. This is obviously not the case, as the water mass has been away from the surface for a number of years so we would expect oxygen concentrations to decrease gradually to due ageing. Therefore the LSW that reached the Rockall Trough in 1996, 2008, 2009 and 2010 was likely between $90-100 \%$ saturated when it was formed (Table 2).

Vertical nutrient profiles (Fig. 6) indicate a weak minimum for $\mathrm{NO}_{3}$ and $\mathrm{PO}_{4}$ in $\mathrm{LSW}$, however these minima are not as clearly defined as the salinity or oxygen extremes. The $\mathrm{NO}_{3}{ }^{\circ}$ (calculated at $100 \%$ saturation) for LSW in 2009 is marginally lower than 2008 and 2010, which may be due to a difference in oxygen saturation when the water mass was formed, or may also be related to the lower salinity and lower silicate measured in LSW that year (Table 2). The $\mathrm{PO}_{4}$ across the southern transect is lower in 2008 than in 2009/10, and this low- $\mathrm{PO}_{4}$ signal is seen in the northern transect in 2009. AR24 Si data in the northern transect is slightly higher than recent years, coincident with a higher salinity (34.94). While NP ratios are $~ 16$ in LSW in 2009/10, they are generally lower through the water column in 1996 data, with an average NP of 15 in LSW. 
In the deepest waters in the Trough, there is a slight increase in salinity and decrease in temperature below LSW; typical of NEADW. The gradual increase in AOU below 2000m (Fig. 5) suggests ageing of this water mass, as oxygen gets used up by remineralisation and dissolved inorganic nutrients are released into the water column. Nutrient concentrations consequently increase with depth, ranging from 18 to $24 \mu \mathrm{mol}$ $\mathrm{kg}^{-1} \mathrm{NO}_{3}, 17$ to $42 \mu \mathrm{mol} \mathrm{kg}{ }^{-1} \mathrm{Si}$ and 1.1 to $1.4 \mu \mathrm{mol} \mathrm{kg}{ }^{-1} \mathrm{PO}_{4}$ between $2500 \mathrm{~m}$ to $3000 \mathrm{~m}$ (Fig. 6 and 7). Maximum values are found at the southern transect generally below $3000 \mathrm{~m}$, reaching $22 \mu \mathrm{mol} \mathrm{kg}{ }^{-1} \mathrm{NO}_{3}, 42 \mu \mathrm{mol} \mathrm{kg}{ }^{-1} \mathrm{Si}$ and $1.5 \mu \mathrm{mol} \mathrm{kg}{ }^{-1} \mathrm{PO}_{4}$. Such high values are seen in all deep waters (>3000m) of the Trough in 1996 and 2010, on the western side in 2008 and on the eastern side in 2009 (Table 2). Lowest NP ratios were measured in the deepest part of the Trough in all years $(\sim 15)$.

\section{Discussion}

Low nutrient levels were measured in the surface mixed layer each year; surface waters of the N. Atlantic are generally depleted in nutrients during spring and summer months due to biological activity (photosynthesis), and while entrainment of deeper waters due to deep winter convection increases nutrient concentrations, levels remain lower than the rest of the water column (Fig. 6). Nutrient concentrations are lower in the surface mixed layer in 1996 relative to 2008, 2009 and 2010, particularly seen for $\mathrm{NO}_{3}$. A first glance would suggest that lower $\mathrm{NO}_{3}$ is due to some biological activity in surface waters of the 1996 survey; however a positive AOU suggests photosynthesis is not occurring in the surface layer. Sampling of WOCE-AR24 occurred at the end of November 1996 in the southern Rockall region, while it occurred in February in 2008, 2009 and 2010. Warmer surface waters and a shallower winter mixed layer in 1996 suggests winter mixing had only begun to break down the seasonal thermocline and 
deep winter convection may not have fully replenished surface waters with subsurface nutrients. This highlights the important role of physical mixing in replenishing nutrients to the surface waters of the Trough.

In 1996, 2008 and 2009, upper ENAW on the eastern side of the Trough is slightly warmer, more saline, with fewer nutrients relative to the western side (Fig 7. and 8). This supports previous studies that suggested ENAW is cooled and freshened as it moves north from its formation region in the Bay of Biscay (Pollard et al., 1996) by cooler, fresher water moving in from the western North Atlantic with the NAC (Ellett, 1995). Read (2001) also identified the NAC by a slight freshness in the warm saline water of the upper eastern North Atlantic. The NAC transports nutrients to the northern North Atlantic (Pelegri et al., 1996), which can be seen in the elevated nutrient levels in the colder, less saline water moving in from the west. Also, upwelling in the subpolar gyre results in nutrient-rich surface water (Williams and Follows, 2003) which is being mixed with the upper ENAW as it is moving north through the Rockall Trough. Surface plots of the entire WOCE-AR24 survey (not shown here), indicate surface nutrient values increase steadily from a minimum along the transect in the Porcupine Sea Bight, to a surface maximum along the northern transect of the Rockall Trough. This can be seen in 1996, 2008 and 2009 right down to $1000 \mathrm{~m}$. In 2010 , this nutrient-rich, fresher water is found further east into the Trough closer to the continental shelf and is possibly indicative of an elevated NAC/subpolar gyre influence that year (Fig. 8). There are clearly higher remineralisation rates between $500-600 \mathrm{~m}$ at the western side of the Trough, indicated by elevated AOU and nutrient levels relative to the eastern side. This may be due to 
higher flux of particulate matter from the subpolar gyre, an area of high primary productivity (Williams and Follows, 2003).

Below the winter mixed layer, oxygen concentration decreases rapidly (Fig. 5), which could be in part due to remineralisation of sinking organic material below the thermocline, and/or the mixing with a water mass with lower oxygen content. The increase in AOU in this region (Fig. 5) suggests biologically induced consumption of oxygen and subsequent release of inorganic nutrients has occurred in the water column, typical of water below the permanent thermocline. The increase in Si with depth (Fig. 6c) is much smaller than that seen for $\mathrm{NO}_{3}$ and $\mathrm{PO}_{4}$ due to the relatively slower remineralisation of silica from sinking particles (Gnanadesikan, 1999). This allows for Si to be used as an effective tracer of water masses since concentrations are not as quickly altered by biological activity.

The high salinity, low oxygen core along the continental shelf-break of the southern transect is indicative of a MW signal, which is restricted to a few stations near the shelf in 2008 and 2010, but has a wider spread in 1996 and 2009 (Fig. 8). Upon formation in the oligotrophic Mediterranean Sea, MW is relatively low in oxygen and nutrients (Cabecadas et al., 2002; Howe et al., 1974; Tsuchiya et al., 1992). Cabaecadas et al. (2002) found that $\mathrm{NO}_{3}$ and $\mathrm{PO}_{4}$ concentrations increased slightly in MW between the Gulf of Cadiz and a transect north of its origin due to mixing with overlying nutrient-rich Antarctic Intermediate Water (AAIW), however there was no increase in $\mathrm{Si}$. The lower $\mathrm{Si}, \mathrm{NO}_{3}{ }^{\circ}$ and $\mathrm{PO}_{4}{ }^{\circ}$ values measured in this core each year agrees with van Aken (2000b), who stated that despite mixing with AAIW after 
formation, MW is characterised by relatively low preformed nutrients. van Aken (2000b) also suggested MW is characterised by low AOU, however the ageing of this water mass along its pathway to the Rockall Trough has increased the AOU and dissolved inorganic nutrients to the higher levels measured here. In 2008-2010, the $\mathrm{N}^{\circ}: \mathrm{P}^{\circ}$ ratio was relatively high at a few stations in the MW core. This also supports a MW origin, since the Mediterranean Sea has a high NP ratio (22) (Bethoux et al., 1999) due to increased N:P inputs, low levels of denitrification and possibly fixation of atmospheric dinitrogen (Ridame et al., 2003). Perez et al. (1993) also measured elevated $\mathrm{N}^{\circ} \mathrm{P}^{\mathrm{o}}$ ratios in the MW core along the Iberian Peninsula.

Between 700-1000m stations along western side of the southern transect in 2008 and 2009, and stations at the centre of the Trough in 2010, have salinity and temperature values typical of SAIW in the Rockall Trough (Ullgren and White, 2010). This water has higher oxygen, lower AOU, and higher nutrients than the rest of the Trough at that depth. Low salinity and high oxygen content is due to the influence from the Labrador Current during formation in the western subpolar gyre (Wade et al., 1997). AOU and preformed nutrients were calculated at a range of initial saturation states, to account for the possibility of this water mass being undersaturated with oxygen depending on the rate of subduction when it was formed. As the saturation state may vary between years, comparison of AOU and preformed nutrients over a number of years should be studied with caution. Preformed nutrients and AOU, can however be used to distinguish between SAIW and surrounding water masses. Regardless of the initial saturation level, SAIW has higher preformed nutrients and lower AOU than the surrounding water at that depth, indicating that the elevated nutrients are not due to biological activity, and it is likely that these nutrients have been entrained from the 
subpolar gyre when SAIW was formed. $\theta-$ S profiles indicate that the SAIW signal is stronger in 2010 than the previous 2 years, which would explain why it is found closer to the continental shelf than 2008/09. This could be the reason why MW was more confined to the shelf edge in 2010 , since these two water masses have similar density and so have been found to 'compete' for space at the same depth in the water column. Mohn et al. (2002) suggested SAIW could be a barrier for the northward transport of MW along the Porcupine Bank. Preformed nutrient levels and oxygen are higher in SAIW than in MW and therefore concentrations can also be used to distinguish between the two water masses in the region.

The decrease in oxygen and increase in nutrients below the permanent thermocline occurs slightly deeper in the water column in the northern transects. This reflects both increased levels of mixing of intermediate water masses moving north in the Trough, and also the absence of SAIW, which is a highly stratified water mass that can result in a stable layer at intermediate depths, restricting the maximum depth of winter mixing (Wade et al., 1997). In the northern transects some of the data points between 800-1100m near the Rockall Bank tend towards higher salinity along the WTOW mixing line (Fig. 4b). If the $\theta$-S plots of northern and southern transects were plotted together, this $\theta-\mathrm{S}$ signal could be mistaken for $\mathrm{MW}$, which is also seen as an inflexion in the $\theta$-S plots towards higher salinity. However, WTOW has higher oxygen content than that of MW seen in the south. While McCartney and Mauritzen (2001) measured lower nutrients and higher oxygen in the slightly more saline WTOW, few data points in $2009 / 10$ make it difficult to accurately describe the chemical characteristics of this water mass in the region. 
LSW occupies most of water column between 1500-2000m deep and properties are typical of LSW in the Rockall Channel (Stoll et al., 1996). The high oxygen content seen at that depth is characteristic of LSW as it is a young water mass relatively recently in contact with the atmosphere. Oxygen levels are even higher than surface waters in the Trough, since LSW is also much colder and therefore capable of absorbing more oxygen during formation. LSW in the northern transects is slightly warmer and more saline and with lower oxygen than the LSW in the southern transects. This supports New and Smythe-Wright (2001) who also reported an increase in salinity in LSW exiting the Trough due to mixing with surrounding water masses.

Due to varying convection regimes in the Labrador Sea, the oxygen concentration may vary to due the level of mixing between the sinking, oxygen-rich surface water with the rising deeper water which is lower in oxygen. Azetsu-Scott et al. (2005) measured average saturation levels of $77 \%$ for CFC-12 for the entire Labrador Sea in May/June 1997, with significant horizontal and vertical variability. For each year, at saturation states less than $85 \%$, the average AOU was negative, and preformed nutrient values higher than actual values measured. Therefore the LSW that reached the Trough in 1996, 2008, 2009 and 2010, was likely 90-100\% saturated during formation, since LSW has been away from surface waters for a number of years so the dissolved oxygen is likely to decrease slightly, with an increase in dissolved nutrients due to remineralisation.. The weak minima of $\mathrm{PO}_{4}$ and $\mathrm{NO}_{3}$ seen in the $\mathrm{LSW}$ region is similar to that seen along an eastern Atlantic section south of Iceland by Tsuchiya et al. (1992), however these nutrient minima were less clearly defined than the associated oxygen maximum. LSW properties measured in the Rockall Trough 
(averaged over 2008, 2009 and 2010) have been altered slightly with respect to source water properties as defined by BATs (Henry-Edwards and Tomczak, 2005), from 305 to $270 \mu \mathrm{mol} \mathrm{kg}{ }^{-1} \mathrm{O}_{2} ; 16.4$ to $17.6 \mu \mathrm{mol} \mathrm{kg} \mathrm{NO}_{3} ; 9.1$ to $12.1 \mu \mathrm{mol} \mathrm{kg}{ }^{-1} \mathrm{Si}$ and 1.09 to $1.10 \mu \mathrm{mol} \mathrm{kg}{ }^{-1} \mathrm{PO}_{4}$. The increase in nutrients is relatively small between source water and the Rockall Trough due to the short length of time, 10 years (Yashayaev et al., 2007), LSW has been subjected to remineralisation. Calculated preformed nutrient values (at 100\% oxygen saturation) are similar to those from previous studies for LSW in the Eastern North Atlantic (Castro et al., 1998; Pérez et al., 1993; Stoll et al., 1996), however it is difficult to directly compare preformed values between years since the saturation state may have varied depending on convection regimes (AzetsuScott et al., 2005). Severe winters can create mixed layer depths over 1500m deep of colder, less saline LSW, while mild winters cause LSW at intermediate depths to become isolated from the upper mixed layer, becoming warmer and more saline due to mixing with surrounding intermediate water masses (Yashayaev, 2007). Nolan (in prep) recorded a freshening of LSW in the Trough between 2006 and 2009, with a return to higher salinities in 2010. Perhaps this is a delayed response to the shift towards a higher salinity phase of the Labrador Sea from 1994 through to subsequent years reported by Yashayaev (2007). The lower Si measured in LSW in 2009 relative to other years, could be associated with the freshening of LSW that year. The main process responsible for the cooling and freshening of LSW between 1987-1994 was the recurrence of severe winters during these years which resulted in increased winter convection (Yashayaev, 2007). If this was to have any effect on the nutrient concentrations in LSW, it should tend to increase concentrations, with increased convection entraining nutrients from deeper waters. The lower Si in 2009 could therefore indicate more of an influence of the Labrador Current, which is relatively 
cool, fresh and low in $\mathrm{NO}_{3}$ and $\mathrm{Si}$ (Clarke and Coote, 1988; Townsend et al., 2010). This is supported by marginally lower $\mathrm{NO}_{3}{ }^{\circ}$ measured in LSW in 2009. While the lower $\mathrm{NO}_{3}{ }^{\mathrm{o}}$ may also be due to a different saturation state during formation, the $\mathrm{PO}_{4}{ }^{\circ}$ of LSW is the same in 2009 as in 2010 , which may suggest the saturation states were similar each year. The opposite is seen in the 1996 LSW signal in the northern transect, where a higher salinity coincides with slightly elevated Si results. This could indicate a reduced influence from the Labrador Current, or increased mixing with the slightly more saline NEADW, with higher Si concentrations. The lower $\mathrm{PO}_{4}$ in 2008 is difficult to explain. It could be due to unknown local factors or could also indicate mixing with another water mass with lower $\mathrm{PO}_{4}$, e.g. ISOW, however there is little change in salinity or in the other nutrient concentrations to support this statement. The lower $\mathrm{PO}_{4}$ signal of LSW reached the southern entrance to the Rockall Channel in 2008 and can be seen in the northern section of the Trough in 2009, but is not seen again in 2010. While this signal may outline the northward flow of LSW into the Trough the lower $\mathrm{PO}_{4}$ and elevated NP ratios were measured in all deeper waters of 2008, and therefore should be studied with caution.

The decrease in oxygen below LSW (Fig. 5) is due to the presence of NEADW and AABW, both older water masses with a large amount of the oxygen depleted by respiration and remineralisation. This is also illustrated in the higher AOU in these deeper waters. Between 2500-3000m the nutrient values are typical of NEADW, with pronounced vertical gradients (Fig. 6) due to the degree of mixing with the nutrientrich AABW below it (New and Smythe-Wright, 2001). The NP ratios in NEADW and AABW are similar to those reported by Perez et al. (1993) for the same water masses off the Iberian Peninsula. While the temperature and salinity results alone could not 
distinguish between NEADW and AABW, the high nutrient values seen below $3000 \mathrm{~m}$, particularly for $\mathrm{Si}$, clearly indicate this water has a southern origin, i.e. AABW influence. The silicate concentration is particularly high as a large component of AABW is re-cycled deep water with high silicate values (Gnanadesikan, 1999). Highest silicate concentrations are found in different parts of the Trough each year, suggesting that the strength and position of the AABW signal varies between years.

\section{Conclusion}

Temperature and salinity data have been used to identify the water masses present in the Rockall Trough during the winter months of 1996, 2008, 2009 and 2010, and the chemical make up of these water masses has been described. ENAW is progressively cooled and freshened as it moves north through the Rockall Channel, by water masses moving in from the west with the NAC. The NAC tends to elevate nutrient levels in ENAW, with nutrient concentrations increasing moving west and north in the Trough. SAIW and MW, found at a similar density level at the southern entrance to the Trough, can also be identified with their chemical properties; SAIW has relatively high oxygen and high preformed nutrient concentrations, while MW has characteristically low oxygen and low preformed nutrients. While oxygen data can successfully identify LSW in the Trough, nutrient data is less clearly defined. Oxygen and nutrient data, through the calculations of AOU and preformed nutrients, indicate that LSW reaching the Trough in 1996, 2008, 2009 and 2010 was 90-100\% saturated with oxygen when it was formed. Lower silicate, and to a lesser extent preformed nitrate, coincided with a freshening of LSW in 2009, possibly linked to a stronger influence from the Labrador Current when it was formed. Nutrient concentrations, in 
particular silicate, have proved to be effective tracers for AABW, with traces of this water mass found at the southern entrance to the Trough each year.

\section{Acknowledgements}

This study was in part funded by the Irish Government funded project "Impacts of Increased Atmospheric $\mathrm{CO}_{2}$ on Ocean Chemistry and Ecosystems", carried out under the Sea Change strategy with the support of the Marine Institute and the Marine Research Sub-Programme of the National Development Plan 2007-2013. Surveys were funded by the Irish government's National Development Plan 2007-2013. We are grateful to the officers, crew and scientists on the cruises referred to in this paper. We thank Rachel Cave for her comments on the manuscript, Eileen Joyce for her training and help with the nutrient analysis and Kieran Lyons for his help in Matlab. We acknowledge the significant contribution of each of the reviewers to manuscript.

\section{References}

Arhan, M., 1990. The North-Atlantic Current and Sub-Arctic Intermediate Water. Journal of Marine Research 48 (1), 109-144.

Arhan, M., Colin de Verdière, A., Mémery, L., 1994. The Eastern Boundary of the Subtropical North Atlantic. Journal of Physical Oceanography 24, 1295-1316. Azetsu-Scott, K., Jones, E.P., Gershey, R.M., 2005. Distribution and ventilation of water masses in the Labrador Sea inferred from CFCs and carbon tetrachloride. Marine Chemistry 94 (1-4), 55-66.

Bethoux, J.P., Gentili, B., Morin, P., Nicolas, E., Pierre, C., Ruiz-Pino, D., 1999. The Mediterranean Sea: a miniature ocean for climatic and environmental studies 
and a key for the climatic functioning of the North Atlantic. Progress in Oceanography 44 (1-3), 131-146.

Broecker, W.S., Peng, T.H., 1982. Tracers in the sea. Columbia University Press, Palisades, NY.

Bubnov, V.A., 1968. Intermediate subarctic waters in the northern part of the Atlantic Ocean. Okeanologia 19, 136-153.

Cabecadas, G., Brogueira, M.J., Cavaco, M.H., Goncalves, C., 2010. Chemical Signature of Intermediate Water Masses along Western Portuguese Margin. Journal of Oceanography 66 (2), 201-210.

Cabecadas, G., Brogueira, M.J., Goncalves, C., 2002. The chemistry of Mediterranean outflow and its interactions with surrounding waters. Deep-Sea Research Part IiTopical Studies in Oceanography 49 (19), 4263-4270.

Castro, C.G., Perez, F.F., Holley, S.E., Rios, A.F., 1998. Chemical characterisation and modelling of water masses in the Northeast Atlantic. Progress in Oceanography 41 (3), 249-279.

Clarke, R.A., Coote, A.R., 1988. The formation of Labrador Sea-Water. III: The evolution of oxygen and nutrient concentration. Journal of Physical Oceanography 18 (3), 469-480.

Ellett, D.J., 1995. Physical Oceanography of the Rockall Trough. Ocean Challenge 6, $18-23$.

Ellett, D.J., Edwards, A., Bowers, R., 1986. The hydrography of the Rockall Channel - an overview. Proceedings of the Royal Society of Edinburgh 88B, 61-68.

Ellett, D.J., Martin, J.H.A., 1973. Physical and Chemical Oceanography of Rockall Channel. Deep-Sea Research 20 (7), 585-625. 
Gnanadesikan, A., 1999. A global model of silicon cycling: Sensitivity to eddy parameterization and dissolution. Global Biogeochemical Cycles 13 (1), 199220.

Grasshoff, K., Ehrhardt, M., Kremling, K., Almgren, T., 1983. Methods of seawater analysis. Verlag Chemie.

Harvey, J., 1982. Theta-S relationships and water masses in the eastern North Atlantic. Deep-Sea Research Part a-Oceanographic Research Papers 29 (8), 1021-1033.

Harvey, J., Arhan, M., 1988. The water masses of the Central North Atlantic in 198384. Journal of Physical Oceanography 18, 1855-1875.

Henry-Edwards, A., Tomczak, M., 2005. Detecting changes in Labrador Sea Water through water mass analysis of BATS data. Ocean Science Discussions 2, 417435.

Holliday, N.P., Pollard, R.T., Read, J.F., Leach, H., 2000. Water mass properties and fluxes in the Rockall Trough 1975-1998. Deep Sea Research I 47, 1303-1332.

Howe, M.R., Abdullah, M.I., Deetae, S., 1974. Interpretation of Double T-S Maxima in Mediterranean Outflow using Chemical Tracers. Journal of Marine Research $32(3), 377-386$.

Johnson, C., Sherwin, T., Smythe-Wright, D., Shimmield, T., Turrell, W., 2010. Wyville Thomson Ridge Overflow Water: Spatial and temporal distribution in the Rockall Trough. Deep Sea Research Part I: Oceanographic Research Papers $57(10), 1153-1162$.

Koeve, W., 2001. Wintertime nutrients in the North Atlantic--new approaches and implications for new production estimates. Marine Chemistry 74 (4), 245-260. 
Körtzinger, A., Koeve, W., Kähler, P., Mintrop, L., 2001. C : N ratios in the mixed layer during the productive season in the northeast Atlantic Ocean. Deep Sea Research Part I: Oceanographic Research Papers 48 (3), 661-688.

McCartney, M.S., 1992. Recirculating components to the deep boundary current of the northern North Atlantic. Progress in Oceanography 29 (4), 283-383.

McCartney, M.S., Mauritzen, C., 2001. On the origin of the warm inflow to the Nordic Seas. Progress in Oceanography 51 (1), 125-214.

Mohn, C., Bartsch, J., Meincke, J., 2002. Observations of the mass and flow field at Porcupine Bank. Ices Journal of Marine Science 59 (2), 380-392.

New, A.L., Barnard, S., Herrmann, P., Molines, J.M., 2001. On the origin and pathway of the saline inflow to the Nordic Seas: insights from models. Progress in Oceanography 48 (2-3), 255-287.

New, A.L., Smythe-Wright, D., 2001. Aspects of the circulation in the Rockall Trough. Continental Shelf Research 21 (8-10), 777-810.

Nolan, G., in prep. Variability of the intermediate and deep water masses in the Rockall Trough

Pelegri, J.L., Csanady, G.T., Martins, A., 1996. The North Atlantic nutrient stream. Journal of Oceanography 52 (3), 275-299.

Pérez, F.F., Mouriño, C., Fraga, F., Ríos, A.F., 1993. Displacement of water masses and remineralization rates off the Iberian Peninsula by nutrient anomalies. Journal of Marine Research 51, 869-892.

Pollard, R.T., Griffiths, M.J., Cunningham, S.A., Read, J.F., Perez, F.F., Rios, A.F., 1996. Vivaldi 1991-A study of the formation, circulation and ventilation of Eastern North Atlantic Central Water. Progress in Oceanography 37 (2), 167192. 
Read, J.F., 2001. CONVEX-91: water masses and circulation of the Northeast

Atlantic subpolar gyre. Progress in Oceanography 48, 461-510.

Reid, J.L., 1979. Contribution of the Mediterranean Sea outflow to the Norwegian Greenland Sea. Deep-Sea Research Part a-Oceanographic Research Papers 26 (11), 1199-1223.

Ridame, C., Moutin, T., Guieu, C., 2003. Does phosphate adsorption onto Saharan dust explain the unusual N/P ratio in the Mediterranean Sea? Oceanologica Acta $26(5-6), 629-634$.

Sherwin, T.J., Griffiths, C.R., Inall, M.E., Turrell, W.R., 2008. Quantifying the overflow across the Wyville Thomson Ridge into the Rockall Trough. Deep Sea Research Part I: Oceanographic Research Papers 55 (4), 396-404.

Stoll, M.H.C., van Aken, H.M., de Baar, H.J.W., Kraak, M., 1996. Carbon dioxide characteristics of water masses in the northern North Atlantic Ocean. Marine Chemistry 55, 217-232.

Strickland, J.D.H., Parsons, T.R., 1972. A practical handbook of seawater analysis. Fisheries Research Board of Canada.

Thomas, H., 2002. Remineralization ratios of carbon, nutrients, and oxygen in the North Atlantic Ocean: A field databased assessment. Global Biogeochemical Cycles $16(3)$.

Tomczak, M., 1999. Some historical, theoretical and applied aspects of quantitative water mass analysis. Journal of Marine Research 57 (2), 275-303.

Tomczak, M., Godfrey, J.S., 1994. Regional oceanography: An introduction. Oxford, Pergamon. 
Townsend, D.W., Rebuck, N.D., Thomas, M.A., Karp-Boss, L., Gettings, R.M., 2010. A changing nutrient regime in the Gulf of Maine. Continental Shelf Research 30 (7), 820-832.

Tsuchiya, M., Talley, L.D., McCartney, M.S., 1992. An eastern atlantic section from Iceland southward across the equator. Deep-Sea Research Part a-Oceanographic Research Papers 39 (11-12A), 1885-1917.

Ullgren, J.E., White, M., 2010. Water mass interaction at intermediate depths in the southern Rockall Trough, northeastern North Atlantic. Deep Sea Research Part I: Oceanographic Research Papers 57 (2), 248-257.

van Aken, H.M., 2000a. The hydrography of the mid-latitude northeast Atlantic Ocean I: The deep water masses. Deep-Sea Research Part I-Oceanographic Research Papers 47 (5), 757-788.

van Aken, H.M., 2000b. The hydrography of the mid-latitude Northeast Atlantic Ocean II: The intermediate water masses. Deep-Sea Research Part IOceanographic Research Papers 47 (5), 789-824.

van Aken, H.M., Becker, G., 1996. Hydrography and through-flow in the northeastern North Atlantic Ocean: the NANSEN project. Progress in Oceanography 38 (4), 297-346.

Wade, I.P., Ellett, D.J., Heywood, K.J., 1997. The influence of intermediate waters on the stability of the eastern North Atlantic. Deep-Sea Research Part IOceanographic Research Papers 44 (8), 1405-1426.

Wallace, D.W.R., Lazier, J.R.N., 1988. Anthropogenic chlorofluoromethanes in newly formed Labrador Sea Water. Nature 332 (6159), 61-63. 
Williams, R.J., Follows, M.J., 2003. Physical Transport of Nutrients and the Maintenance of Biological Production. In: Fasham, M. (Ed.), Ocean Biogeochemistry: The role of the ocean carbon cycle in global change. Springer. Winkler, L.W., 1988. Die Bestimmung des im Wasser gelösten Sauerstoffen. Berichte der Deutschen Chemischen Gesellschaft 21 (2), 2843-2855.

Worthington, L.V., Wright, W.R., Erika, D., 1970. North Atlantic Ocean atlas: of potential temperature and salinity in the deep water including temperature, salinity and oxygen profiles from the Erika Dan cruise of 1962. Woods Hole Oceanographic Institution.

Yashayaev, I., 2007. Hydrographic changes in the Labrador Sea, 1960-2005. Progress in Oceanography 73 (3-4), 242-276.

Yashayaev, I., van Aken, H.M., Holliday, N.P., Bersch, M., 2007. Transformation of the Labrador Sea Water in the subpolar North Atlantic. Geophysical Research Letters 34 (22), L22605. 
Figures

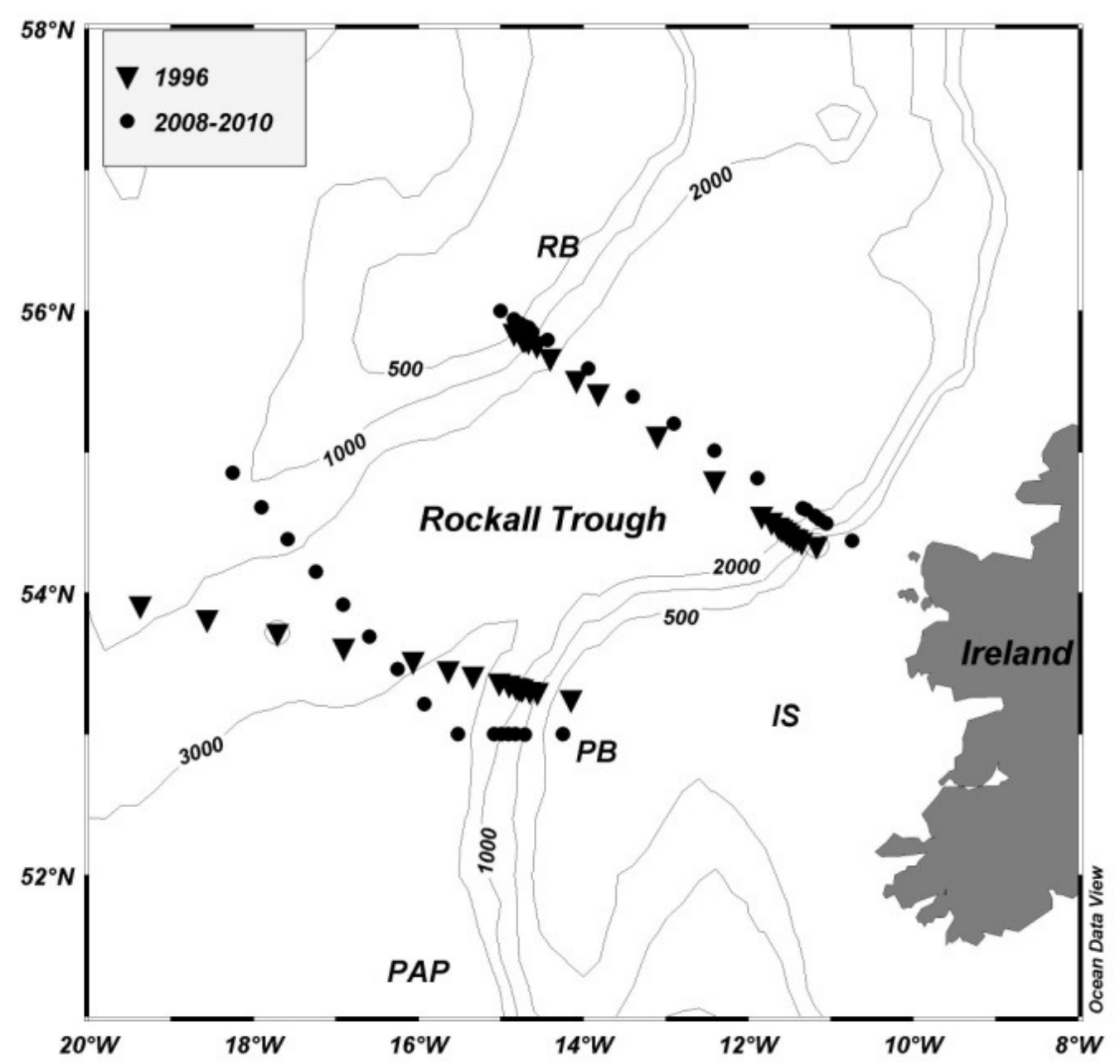

Figure 1. Bathymetry of the Rockall Trough, with transect positions of the 2008, 2009 and 2010 surveys (dots) overlaying the 1996 WOCE AR24 survey (triangles).

Labelled bathymetry: IS- Irish Shelf; PB- Porcupine Bank; RB- Rockall Bank; PAP-

Porcupine Abyssal Plain. 


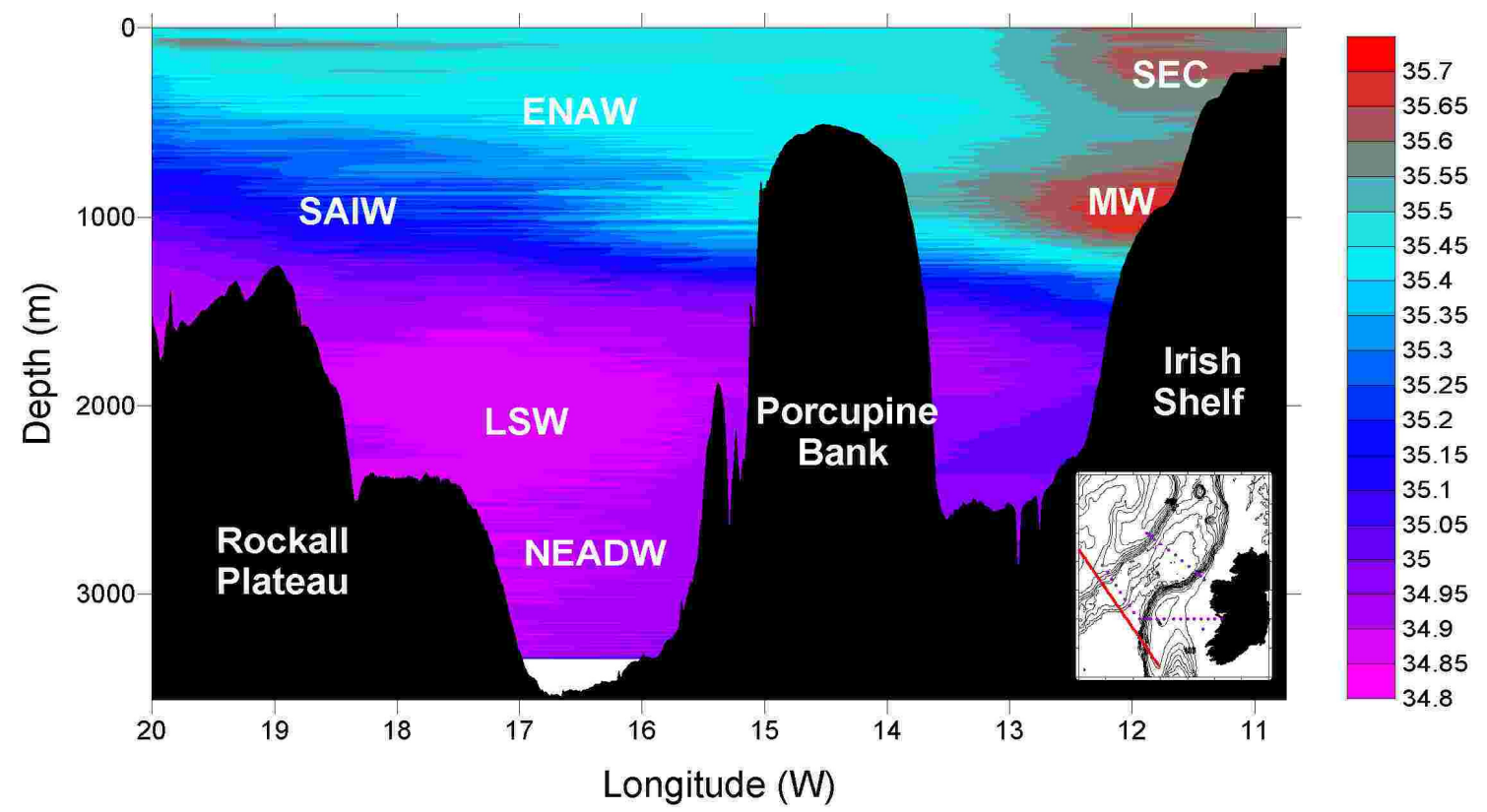

Figure 2. Cross section of salinity along a transect extending from the Irish shelf about $52^{\circ} \mathrm{N}$ across the southern Rockall Trough. Salinity data was taken from a 2010 National Seabed Survey, the red line on the overlay map outlines the transect position relative to surveys discussed in this paper. Water masses outlined in the plot; Eastern North Atlantic Water (ENAW); Shelf Edge Current (SEC); Mediterranean Water (MW); SAIW (Sub Arctic Intermediate Water); Labrador Sea Water (LSW); North East Atlantic Deep Water (NEADW). 

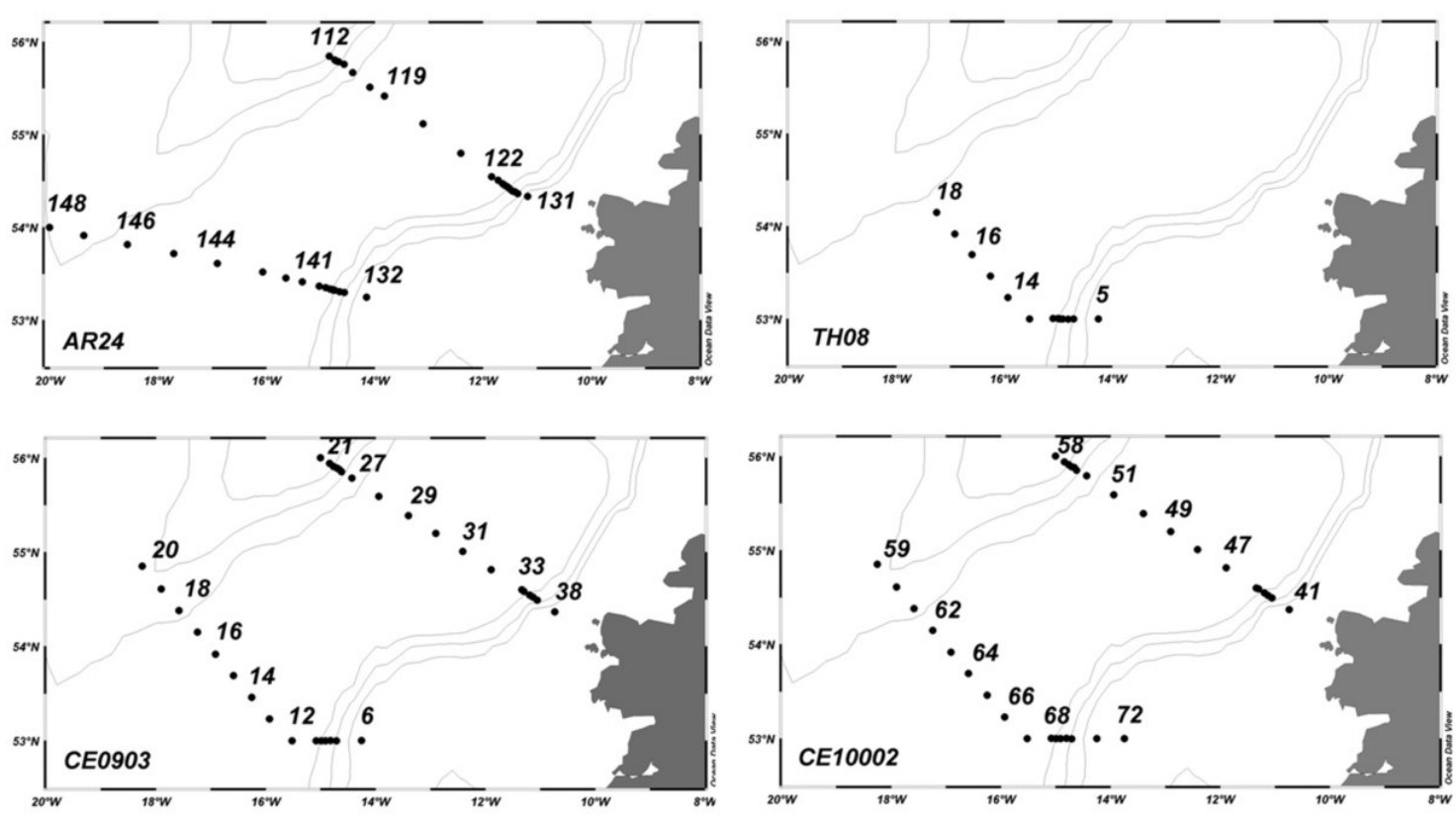

Figure 3. Cruise track and station numbers of WOCE AR24 (Nov/Dec 1996), TH08 (Feb 2008), CE0903 (Feb 2009) and CE10002 (Feb 2010). 

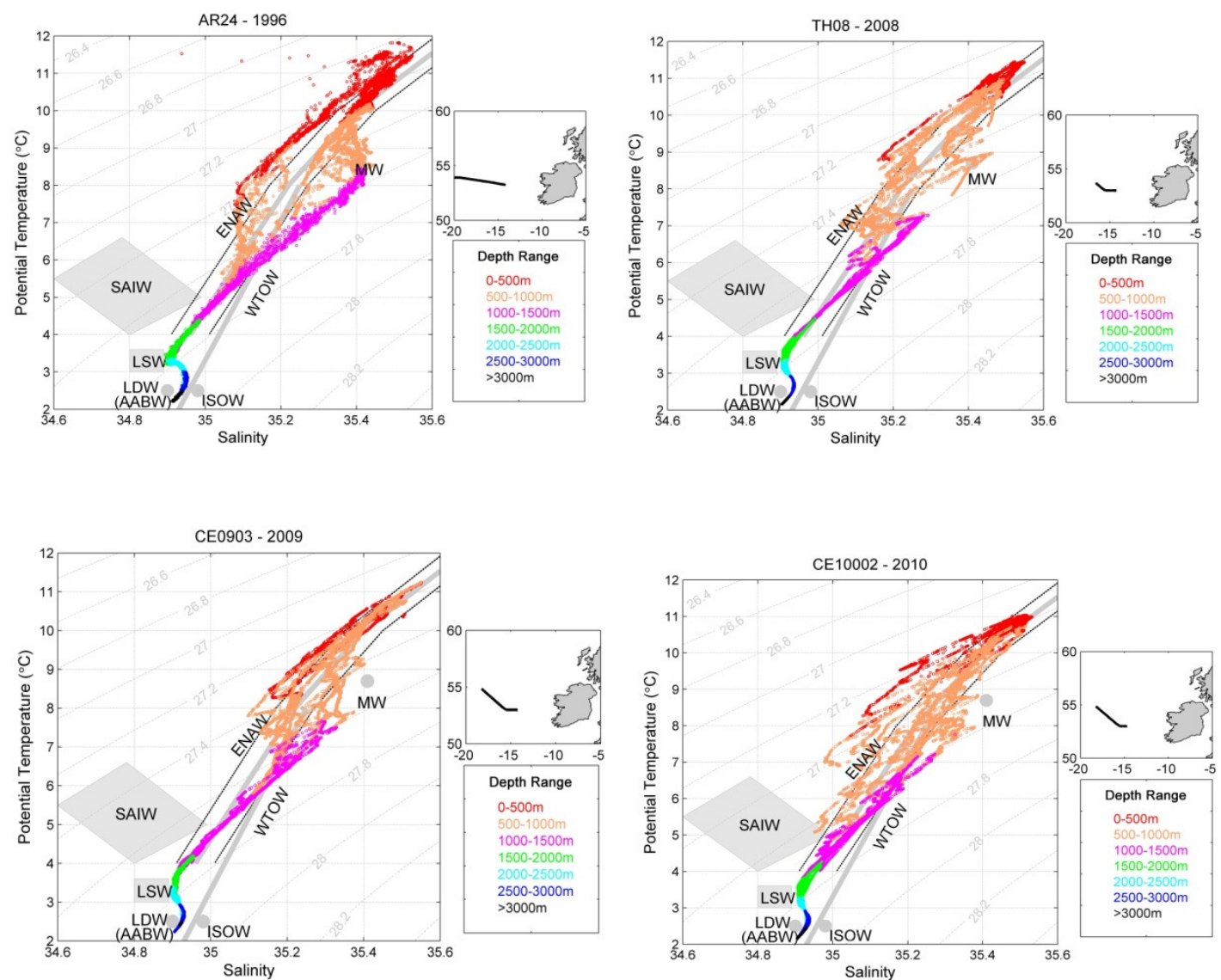

Figure 4. (a) $\theta$-S plots with density contours, using CTD data of the southern transect from (i) AR24, (ii) TH08, (iii) CE0903 and (iv) CE10002. A subplot outlining the transect position is beside each $\theta$-S plot. Water mass properties were taken from the literature: ENAW, MW, LSW and AABW (Harvey, 1982); SAIW (Bubnov, 1968; Harvey and Arhan, 1988); WTOW (Johnson et al., 2010); LDW (Holliday et al., 2000); ISOW (Harvey, 1982; van Aken and Becker, 1996). Note the temperature and salinity of MW is much higher in the source region, properties plotted here are typical of MW in the eastern North Atlantic. 

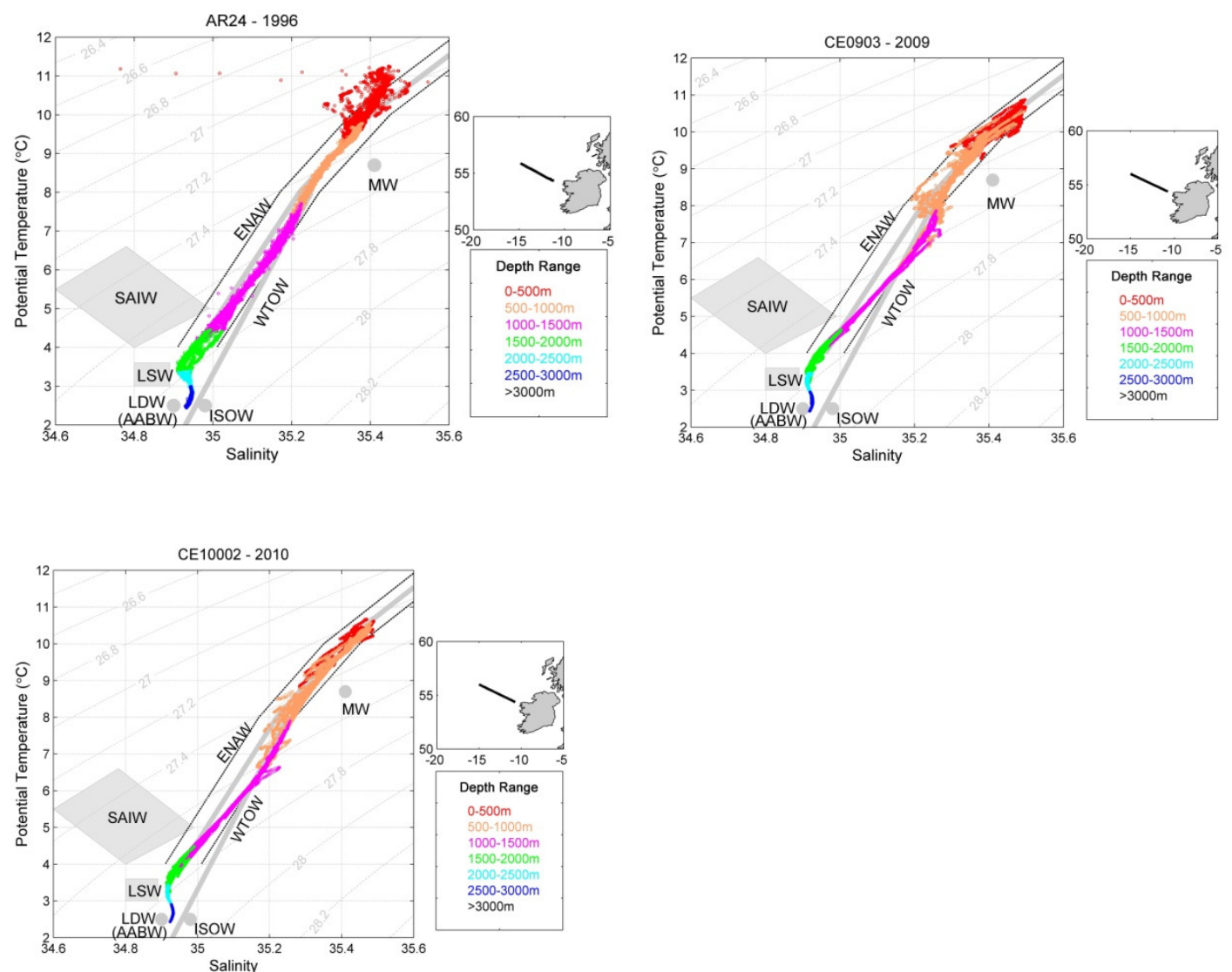

Figure 4. (b) $\theta-\mathrm{S}$ plots of the northern transect from (i) AR24, (ii) CE0903 and (iii) CE10002. References of water masses described in Fig 4 (a). 

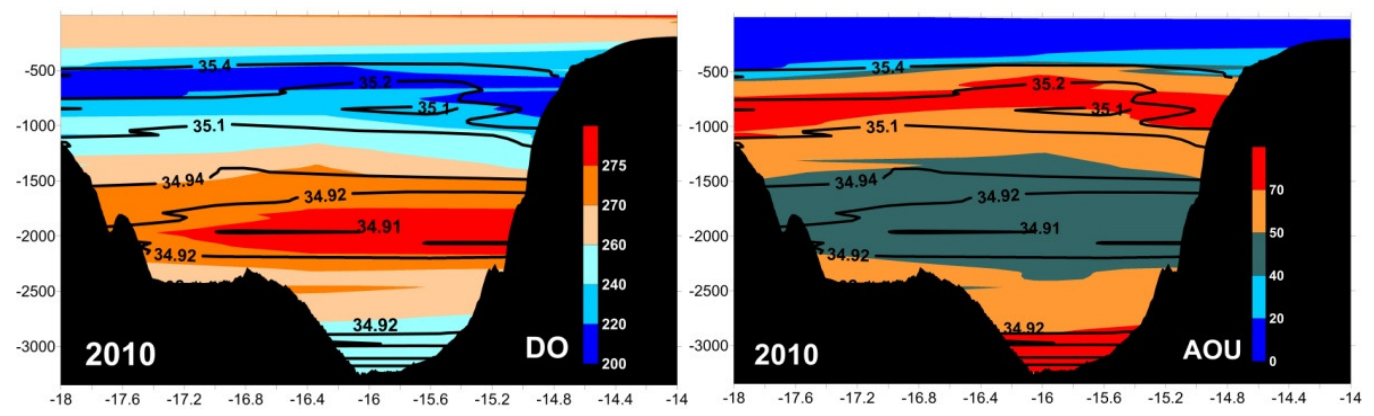

Figure 5 (a).
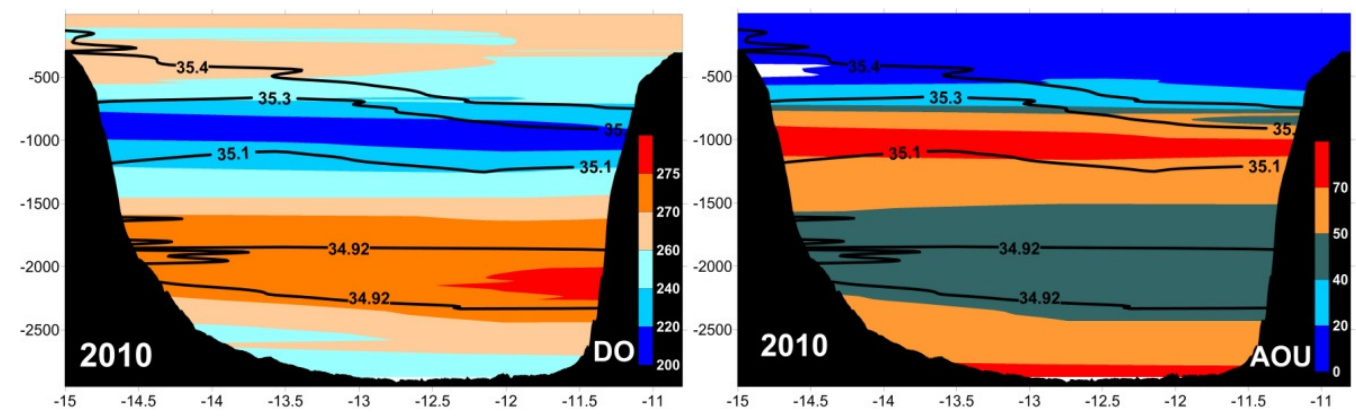

Figure 5 (b)

Figure 5. 2010 section plots of dissolved oxygen (DO) and apparent oxygen utilisation (AOU), both in $\mu \mathrm{mol} \mathrm{kg}{ }^{-1}$, for (a) southern Rockall transect and (b) northern Rockall transect (note plots are from sensor data that have been corrected using Winkler results). 

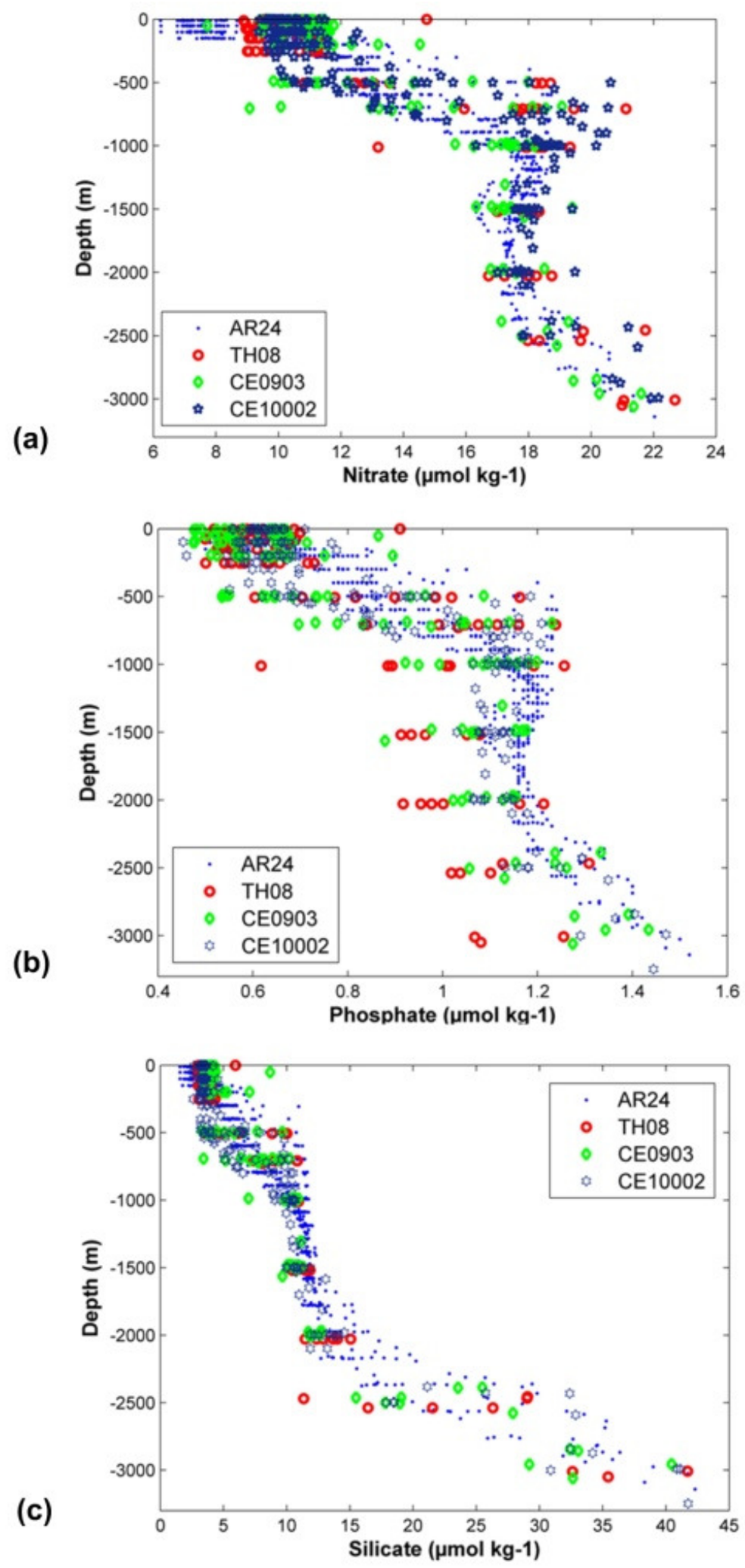

Figure 6. Vertical profiles of (a) nitrate, (b) phosphate and (c) silicate (in $\mu \mathrm{mol} \mathrm{kg}{ }^{-1}$ ) across the both transects in 1996 (AR24), 2008 (TH08), 2009 (CE0903) and 2010 (CE10002). 

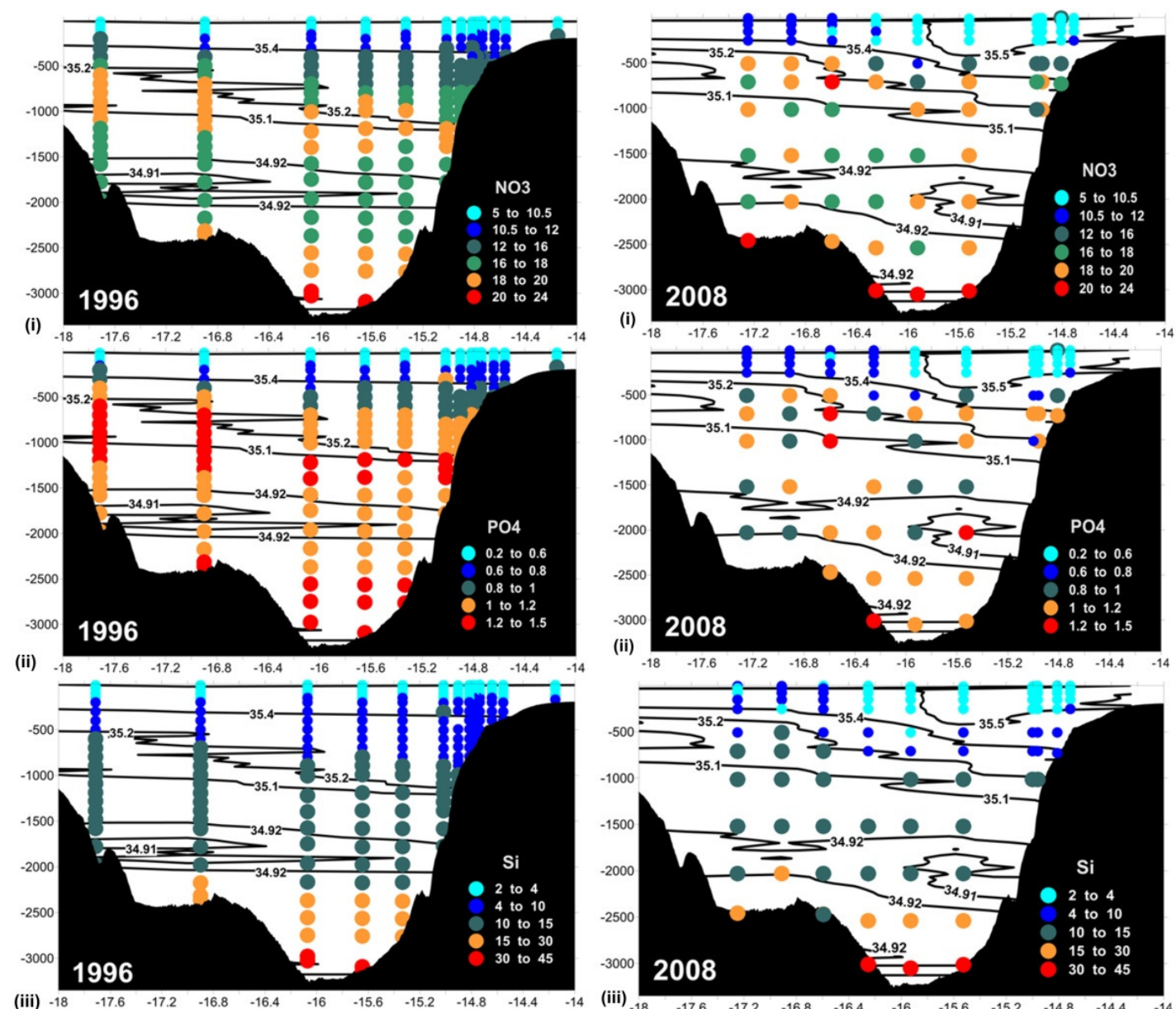

Figure 7 (a)

Figure 7 (b) 

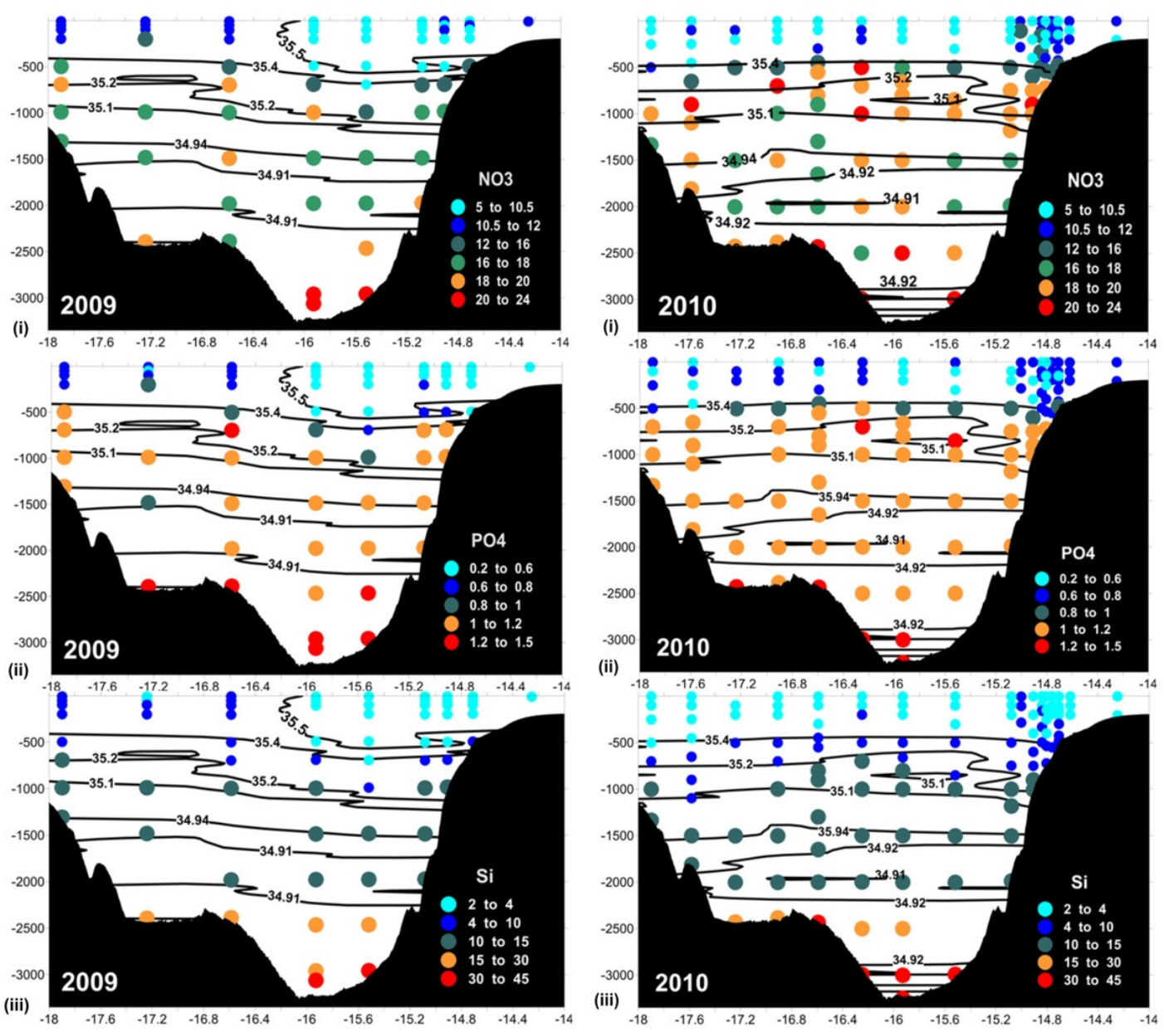

Figure 7 (c)

Figure 7 (d)

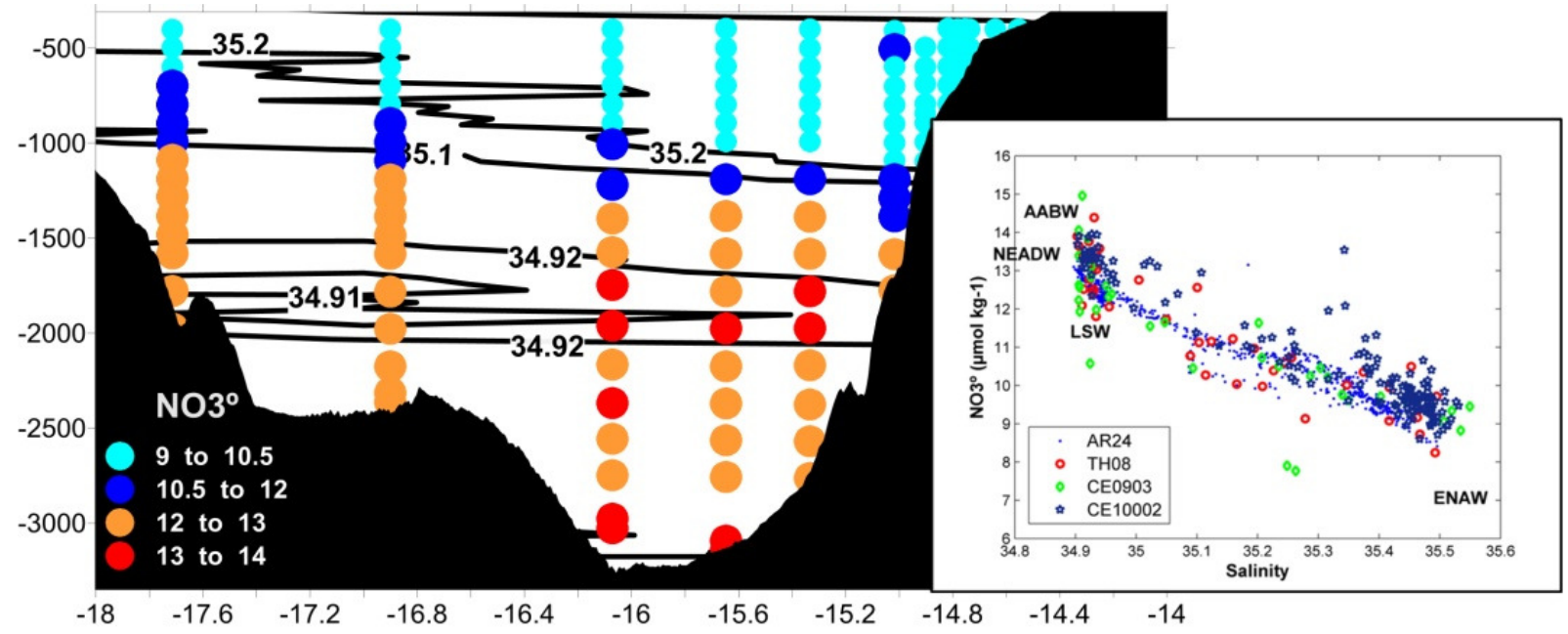

Figure 7 (e) 
Figure 7. Section plots of nutrient concentrations overlaying salinity contours for the southern transects of (a) 1996, (b) 2008, (c) 2009 and (d) 2010 surveys. The section plot of $\mathrm{NO}_{3}{ }^{0}$ with salinity contours in (e) is from 1996, however a similar profile is seen in recent years (not shown here). $\mathrm{NO}_{3}{ }^{0}$ is almost conservative with salinity in all surveys, with a straight mixing line between ENAW and a mixture of LSW, NEADW and $\mathrm{AABW}$. 

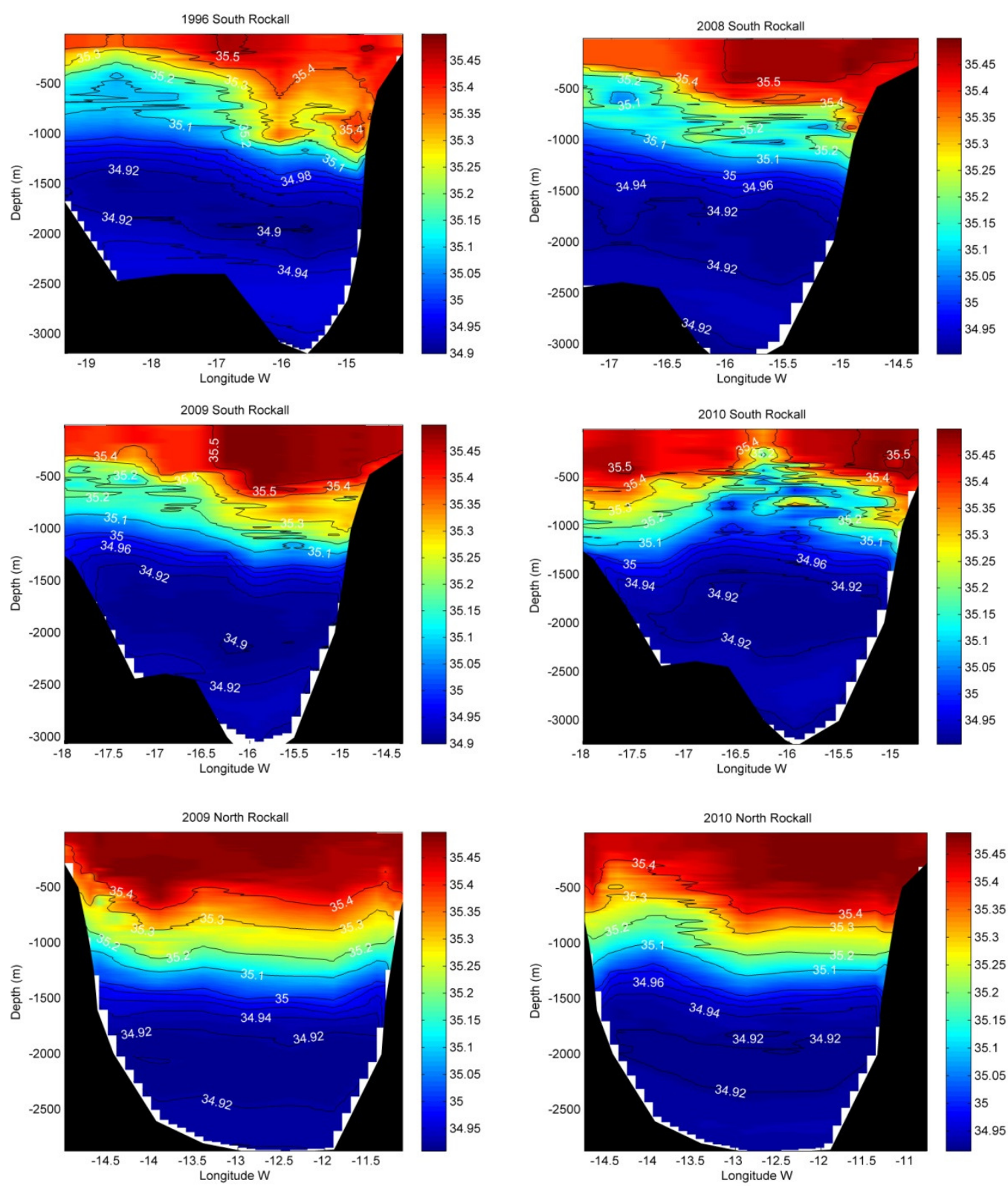

Figure 8. Salinity across the southern Rockall Trough over (a) 1996 (AR24), (b) 2008 (TH08), (c) 2009 (CE0903) and (d) 2010 (CE10002) and across the northern transect in (e) CE0903 and (f) CE10002. 


\section{Tables}

Table 1. Hydrographic characteristics of water masses in the North Atlantic discussed in this paper, taken from the literature, (a) Cabecadas et al., 2010; (b) Castro et al., 1998; (c) Johnson et al., 2010; (d) New and Smythe-Wright, 2001; (e) Perez et al., 1993; (f) Stoll et al., 1996; (g) Thomas, 2002; (h) Tsuchiya et al., 1992; (i) Ullgren and White, 2010. Preformed nutrients are estimated at 100\% oxygen saturation using stoichiometric ratios given by Perez et al. (1993). All chemistry parameters are in $\mu \mathrm{mol} \mathrm{kg}{ }^{-1}$.

\begin{tabular}{|c|c|c|c|c|c|c|c|c|c|c|c|}
\hline $\begin{array}{l}\text { Water } \\
\text { Mass }\end{array}$ & Depth & $\mathbf{S}$ & $\mathbf{T}$ & $\mathbf{O}_{2}$ & AOU & $\mathrm{NO}_{3}$ & $\mathbf{S i}$ & $\mathrm{PO}_{4}$ & $\mathrm{NO}_{3}{ }^{\mathrm{o}}$ & $\mathrm{PO}_{4}{ }^{\circ}$ & Ref \\
\hline ENAW & $0-600$ & $\begin{array}{l}35.4- \\
35.58\end{array}$ & $9-11$ & 200 & 84 & $18-19$ & 8 & 1.1 & 10.3 & 0.58 & $\mathrm{~b}, \mathrm{e}$ \\
\hline MW & $\begin{array}{l}400- \\
1000 \\
\end{array}$ & 36.5 & 11.74 & $\begin{array}{l}145- \\
166 \\
\end{array}$ & $96-117$ & $15-17$ & $10-11$ & $0.9-1$ & 5.4 & 0.32 & $\mathrm{~b}, \mathrm{e}$ \\
\hline SAIW & $\begin{array}{l}600- \\
1000\end{array}$ & $\begin{array}{l}35.1- \\
35.2\end{array}$ & $8-9$ & & 60 & $<13$ & & $<0.9$ & & & $\mathrm{a}, \mathrm{b}, \mathrm{e}, \mathrm{i}$ \\
\hline WTOW & $\begin{array}{l}600- \\
1200\end{array}$ & $\begin{array}{l}34.85- \\
35.25 \\
\end{array}$ & $0.5-8$ & & & & & & & & $\mathrm{c}$ \\
\hline LSW & $\begin{array}{l}1600- \\
1900\end{array}$ & 34.9 & 3.4 & $\begin{array}{l}260- \\
270 \\
\end{array}$ & $45-50$ & $17-19$ & $12.3-14.7$ & $1-1.2$ & $12-14$ & $\begin{array}{l}0.76- \\
0.87\end{array}$ & $\mathrm{~b}, \mathrm{e}, \mathrm{f}$ \\
\hline NEADW & $>2500$ & $\begin{array}{l}34.8- \\
34.92\end{array}$ & 2.5 & $\begin{array}{l}250- \\
270\end{array}$ & $80-90$ & $20-22$ & 37 & $1.4-1.6$ & $13-14$ & $0.8-1$ & $\mathrm{a}, \mathrm{b}, \mathrm{e}, \mathrm{g}$ \\
\hline ISOW & $\begin{array}{l}1800- \\
2000\end{array}$ & $\begin{array}{l}34.96- \\
35\end{array}$ & $<3$ & 286 & 46 & 14.8 & $9-10$ & & 10.2 & & $\mathrm{f}, \mathrm{h}$ \\
\hline LDW & $>2500$ & 34.94 & 2.5 & 246 & 82 & 20.4 & 35.3 & & 12.2 & & $\mathrm{f}$ \\
\hline AABW & $>3000$ & 34.7 & 1 & $<250$ & 90 & $>23$ & $>40$ & $>1.5$ & 26 & 0.94 & $\mathrm{~g}, \mathrm{~d}$ \\
\hline
\end{tabular}


Table 2. Chemical properties of regional water masses after entering the Rockall Trough in 1996 (AR24), 2008 (TH08), 2009 (CE0903) and 2010 (CE10002) for (a) the upper and intermediate water masses, and (b) the deeper masses. Standard deviations are in brackets beside average values. SROCK $=$ southern transect of the Rockall

Trough; NROCK = northern transect of the Rockall Trough; SW = Surface Water; SAIW = Subarctic Intermediate Water; MW = Mediterranean Water; WTOW = WyvilleThomson Overflow Water; LSW = Labrador Sea Water; NEADW = North East Atlantic Deep Water; AABW = Antarctic Bottom Water; $\mathrm{S}=$ salinity; $\mathrm{T}=$ temperature $\left({ }^{\circ} \mathrm{C}\right)$; $\mathrm{DO}=$ dissolved oxygen $\left(\mu \mathrm{mol} \mathrm{kg}{ }^{-1}\right) ; \mathrm{NO}_{3}=$ nitrate; $\mathrm{Si}=$ silicate $; \mathrm{PO}_{4}=$ phosphate $\mathrm{NO}_{3}{ }^{\circ}=$ preformed nitrate; $\mathrm{PO}_{4}{ }^{\circ}=$ preformed phosphate; $\mathrm{n}=$ number of chemistry samples. All nutrients are in $\mu \mathrm{mol} \mathrm{kg}{ }^{-1}$.

Table 2 (a)

\begin{tabular}{|c|c|c|c|c|c|c|c|c|c|c|c|c|c|c|c|}
\hline $\begin{array}{l}\text { Water } \\
\text { bodies }\end{array}$ & Section & Year & Depth & Stations & $\mathbf{S}$ & $\mathbf{T}$ & DO & $\%$ sat & AOU & $\mathrm{NO}_{3}$ & $\mathbf{S i}$ & $\mathrm{PO}_{4}$ & $\mathrm{NO}_{3}^{\circ}$ & $\mathrm{PO}_{4}{ }^{\circ}$ & $\mathbf{n}$ \\
\hline \multirow[t]{6}{*}{ SW } & SROCK & 2010 & $0-300$ & All & $35.47(0.1)$ & $10.78(0.3)$ & $261(4.2)$ & & $7.67(4)$ & $10.1(0.5)$ & $3.37(0.3)$ & $0.60(0.1)$ & & & 38 \\
\hline & & 2009 & $0-300$ & $7-14$ & $35.53(0.01)$ & $11.17(0.1)$ & $259(0.5)$ & & $7.79(0.6)$ & $10(0.4)$ & $3.45(0.1)$ & $0.54(0.04)$ & & & 20 \\
\hline & & & & $15-20$ & $35.44(0.02)$ & $10.52(0.2)$ & $259(1.3)$ & & $11.3(1.3)$ & $11.4(1)$ & $4.38(0.9)$ & $0.66(0.1)$ & & & 13 \\
\hline & & 2008 & $0-300$ & $6-15$ & $35.52(0.02)$ & $11.35(0.1)$ & $261(2.2)$ & & $5.3(2.4)$ & $9.67(0.9)$ & $3.25(0.5)$ & $0.57(0.1)$ & & & 38 \\
\hline & & & & $16-18$ & $35.41(0.02)$ & $10.57(0.1)$ & $262(1.5)$ & & $7.9(1.5)$ & $11(0.4)$ & $4.06(0.1)$ & $0.67(0.03)$ & & & 13 \\
\hline & & 1996 & $0-150$ & All & $35.45(0.1)$ & $11.26(0.2)$ & $259(1.7)$ & & $6.99(1.4)$ & $7.1(0.4)$ & $2.03(0.3)$ & $0.52(0.02)$ & & & 52 \\
\hline \multirow[t]{3}{*}{ SW } & NROCK & 2010 & $0-300$ & All & $35.46(0.03)$ & $10.39(0.2)$ & $261(3.5)$ & & $10.5(3.7)$ & $10.7(0.6)$ & $3.44(0.4)$ & $0.65(0.1)$ & & & 45 \\
\hline & & 2009 & $0-300$ & All & $35.47(0.02)$ & $10.45(0.3)$ & $261(1.7)$ & & $9.5(1.8)$ & $11.2(0.8)$ & $4.18(0.9)$ & $0.62(0.1)$ & & & 33 \\
\hline & & 1996 & $0-150$ & All & $35.4(0.1)$ & $10.96(0.3)$ & $260(2.5)$ & & $8.48(0.9)$ & $7.87(0.3)$ & $2.82(0.2)$ & $0.55(0.02)$ & & & 77 \\
\hline \multirow[t]{4}{*}{ ENAW } & SROCK & 2010 & $0-700$ & $\begin{array}{l}67-73 \\
59-66\end{array}$ & $\begin{array}{l}35.08-35.53 \\
34.98-35.52\end{array}$ & $\begin{array}{l}7.53-11.06 \\
6.41-11.01\end{array}$ & $202-269$ & & $2.32-82.2$ & $9.37-20.6$ & $3.07-10.1$ & $0.45-1.21$ & & & 59 \\
\hline & & 2009 & $0-700$ & $\begin{array}{l}7-14 \\
15-20\end{array}$ & $\begin{array}{l}35.23-35.55 \\
35.10-35.47\end{array}$ & $\begin{array}{l}8.94-11.34 \\
6.93-10.91\end{array}$ & $209-262$ & & $6.52-75.4$ & $9.41-19.1$ & $3.29-10.3$ & $0.47-1.23$ & & & 44 \\
\hline & & 2008 & $0-700$ & $\begin{array}{l}6-15 \\
16-18\end{array}$ & $\begin{array}{l}35.19-35.55 \\
35.04-35.42\end{array}$ & $\begin{array}{l}8.89-11.5 \\
6.93-10.73\end{array}$ & $202-264$ & & $2.1-85.6$ & $8.89-21.1$ & $2.98-10.9$ & $0.5-1.24$ & & & 71 \\
\hline & & 1996 & $0-700$ & $\begin{array}{l}132-143 \\
144-148 \\
\end{array}$ & $\begin{array}{l}35.1-35.55 \\
35.08-35.55 \\
\end{array}$ & $\begin{array}{l}8.9-11.58 \\
6.37-11.84 \\
\end{array}$ & $206-263$ & & $5.58-82.9$ & $6.23-18.72$ & $1.56-11.43$ & $0.48-1.24$ & & & 163 \\
\hline \multirow[t]{3}{*}{ ENAW } & NROCK & 2010 & $0-700$ & All & $35.21-35.5$ & $7.58-10.68$ & $210-269$ & & $1.47-76.2$ & $9.65-18.0$ & $2.61-6.71$ & $0.55-0.96$ & & & 64 \\
\hline & & 2009 & $0-700$ & All & $35.19-35.5$ & $8.18-10.92$ & $214-266$ & & $5.76-70.3$ & $7.73-18.6$ & $3.54-9.35$ & $0.48-1.1$ & & & 48 \\
\hline & & 1996 & $0-700$ & All & $35.25-35.55$ & $8.44-11.27$ & $224-267$ & & $7.52-53.0$ & $7.42-14.8$ & $2.44-7.91$ & $0.52-0.98$ & & & 210 \\
\hline \multirow[t]{4}{*}{ SAIW } & SROCK & 2010 & $700-1000$ & 64-66 & $35.08(0.1)$ & $5.93(0.8)$ & $248(2.2)$ & $\begin{array}{l}100 \% \\
85 \%\end{array}$ & $\begin{array}{l}57.3 \\
11.5(1.5)\end{array}$ & $19.0(0.9)$ & $10.5(0.2)$ & $1.12(0.03)$ & $\begin{array}{l}13.2 \\
17.7(1)\end{array}$ & $\begin{array}{l}0.77 \\
1.07(0.05)\end{array}$ & 6 \\
\hline & & 2009 & $700-1000$ & $17-20$ & $35.12(0.1)$ & $6.05(0.6)$ & $250(3.1)$ & $\begin{array}{l}100 \% \\
85 \%\end{array}$ & $\begin{array}{l}57.1 \\
11.1(2)\end{array}$ & $17.3(0.3)$ & $10.7(0.4)$ & $1.12(0.1)$ & $\begin{array}{l}11.6 \\
16.2(0.05)\end{array}$ & $\begin{array}{l}0.77 \\
1.05(0.1)\end{array}$ & 2 \\
\hline & & 2008 & $800-1000$ & $16-18$ & $35.11(0.04)$ & $5.79(0.5)$ & $243(8.9)$ & $\begin{array}{l}100 \% \\
85 \%\end{array}$ & $\begin{array}{l}62.5 \\
16.6(6.1)\end{array}$ & $18.1(0.3)$ & $10.8(0.1)$ & $1.05(0.2)$ & $\begin{array}{l}11.9 \\
16.5(0.9)\end{array}$ & $\begin{array}{l}0.67 \\
0.95(0.2)\end{array}$ & 3 \\
\hline & & 1996 & $800-1000$ & $144-148$ & $35.08(0.04)$ & $5.73(0.5)$ & $234(8.1)$ & $\begin{array}{l}100 \% \\
85 \%\end{array}$ & $\begin{array}{l}70.1 \\
24.5(5.2)\end{array}$ & $18.5(0.1)$ & $11.5(0.1)$ & $1.22(0.01)$ & $\begin{array}{l}11.5 \\
16.1(0.4)\end{array}$ & $\begin{array}{l}0.80 \\
1.07(0.03)\end{array}$ & 10 \\
\hline \multirow[t]{4}{*}{ MW } & SROCK & 2010 & $700-800$ & $70-71$ & $35.36(0.03)$ & $9.18(0.3)$ & $203(2.9)$ & & $75.6(5.4)$ & $18.3(0.4)$ & $8.6(0.4)$ & $1.09(0.1)$ & $10.7(0.8)$ & $0.63(0.06)$ & 2 \\
\hline & & 2009 & 1000 & $9-13$ & $35.32(0.04)$ & $9.28(0.4)$ & $211(1.1)$ & & $76.8(1)$ & $17.3(1.1)$ & $9.6(1.7)$ & $1.10(0.1)$ & $9.59(1.2)$ & $0.63(0.1)$ & 4 \\
\hline & & 2008 & $700-800$ & & $35.35(0.1)$ & $9.26(0.5)$ & $200(4.5)$ & & $76.2(5.8)$ & $17.9(0.2)$ & $8.5(0.7)$ & $1.05(0.03)$ & $10.3(0.3)$ & $0.65(0.01)$ & 2 \\
\hline & & 1996 & $700-900$ & $134-140$ & $35.38(0.03)$ & $9.12(0.2)$ & 205 (3.9) & & $74.6(4.3)$ & $16.9(0.4)$ & $9.3(0.5)$ & $1.09(0.02)$ & $9.39(0.1)$ & $0.63(0.01)$ & 14 \\
\hline \multirow[t]{2}{*}{ WTOW } & NROCK & 2010 & $800-1100$ & $50-51$ & $35.03-35.26$ & $5.02-7.81$ & 237 & & 66.6 & 17.9 & 10.7 & 1.12 & 11.4 & 0.71 & 1 \\
\hline & & 2009 & $800-1100$ & $27-28$ & $35.12-35.35$ & $5.99-9.48$ & 214 & & 73.7 & 17.4 & 9.8 & 0.99 & 10.1 & 0.54 & 1 \\
\hline
\end{tabular}


Table 2 (b)

\begin{tabular}{|c|c|c|c|c|c|c|c|c|c|c|c|c|c|c|c|}
\hline $\begin{array}{l}\text { Water } \\
\text { bodies }\end{array}$ & Section & Year & Depth & Stations & $\mathbf{S}$ & $\mathbf{T}$ & DO & $\%$ sat & AOU & $\mathrm{NO}_{3}$ & $\mathbf{S i}$ & $\mathrm{PO}_{4}$ & $\mathrm{NO}_{3}{ }^{\circ}$ & $\mathrm{PO}_{4}{ }^{\circ}$ & $\mathbf{n}$ \\
\hline \multirow[t]{4}{*}{ LSW } & SROCK & 2010 & $1500-2000$ & All & $34.92(0.01)$ & $3.67(0.2)$ & $273(4)$ & $\begin{array}{l}100 \% \\
90 \%\end{array}$ & $\begin{array}{l}44 \\
12.2(2.2)\end{array}$ & $18.0(0.7)$ & $12.3(1.1)$ & $1.09(0.03)$ & $\begin{array}{l}13.3 \\
16.5(0.3)\end{array}$ & $\begin{array}{l}0.81 \\
1.01(0.02)\end{array}$ & 9 \\
\hline & & 2009 & $1500-2000$ & All & $34.91(0.01)$ & $3.65(0.2)$ & $271(4.9)$ & $\begin{array}{l}100 \% \\
90 \%\end{array}$ & $\begin{array}{l}46.4 \\
14.7(2.3)\end{array}$ & $17.4(1)$ & $11.5(1.1)$ & $1.11(0.1)$ & $\begin{array}{l}12.8 \\
16.0(1)\end{array}$ & $\begin{array}{l}0.82 \\
1.02(0.1)\end{array}$ & 10 \\
\hline & & 2008 & $1500-2000$ & All & $34.92(0.02)$ & $3.7(0.26)$ & $271(3.4)$ & $\begin{array}{l}100 \% \\
90 \%\end{array}$ & $\begin{array}{l}46.9 \\
15.1(1.7)\end{array}$ & $17.8(0.6)$ & $12.2(1.5)$ & $1.01(0.1)$ & $\begin{array}{l}13.1 \\
16.3(0.7)\end{array}$ & $\begin{array}{l}0.73 \\
0.92(0.1)\end{array}$ & 12 \\
\hline & & 1996 & $1500-2000$ & All & $34.92(0.02)$ & $3.69(0.3)$ & $272(4.9)$ & $\begin{array}{l}100 \% \\
90 \%\end{array}$ & $\begin{array}{l}45.5 \\
13.8(3.5)\end{array}$ & $17.4(0.2)$ & $12(0.7)$ & $1.16(0.01)$ & $\begin{array}{l}12.8 \\
16.0(0.2)\end{array}$ & $\begin{array}{l}0.88 \\
1.08(0.01)\end{array}$ & 34 \\
\hline \multirow[t]{3}{*}{ LSW } & NROCK & 2010 & $1500-2000$ & All & $34.93(0.01)$ & $3.78(0.3)$ & $268(2.7)$ & $\begin{array}{l}100 \% \\
90 \%\end{array}$ & $\begin{array}{l}47.6 \\
16(2.7)\end{array}$ & $17.9(0.2)$ & $11.9(1.6)$ & $1.13(1.64)$ & $\begin{array}{l}13.2- \\
16.4(0.2)\end{array}$ & $\begin{array}{l}0.86- \\
1.04(0.02)\end{array}$ & 8 \\
\hline & & 2009 & $1500-2000$ & All & $34.93(0.02)$ & $3.92(0.3)$ & $265(7)$ & $\begin{array}{l}100 \% \\
90 \%\end{array}$ & $\begin{array}{l}49.3 \\
17.9(3.8)\end{array}$ & $17.4(0.4)$ & $11.2(1)$ & $1.05(0.1)$ & $\begin{array}{l}12.6- \\
15.7(0.6)\end{array}$ & $\begin{array}{l}0.75- \\
0.94(0.1)\end{array}$ & 7 \\
\hline & & 1996 & $1500-2000$ & All & $34.94(0.02)$ & $3.88(0.3)$ & 267 (3.4) & $\begin{array}{l}100 \% \\
90 \%\end{array}$ & $\begin{array}{l}49.1- \\
17.5(2.9)\end{array}$ & $17.3(0.4)$ & $13.04(1.2)$ & $1.16(0.03)$ & $\begin{array}{l}12.4- \\
15.6(0.3)\end{array}$ & $\begin{array}{l}0.86 \\
1.05(0.02)\end{array}$ & 40 \\
\hline \multirow{4}{*}{$\begin{array}{l}\text { NEADW } \\
\text {-upper }\end{array}$} & SROCK & 2010 & $2500-2600$ & All & $34.93(0)$ & $3.03(0.1)$ & $273(4)$ & & $50.1(3.5)$ & $18.3(0.6)$ & $18.2(0.4)$ & $1.16(0.03)$ & 13.9 & $0.81-0.87$ & 3 \\
\hline & & 2009 & $2500-2600$ & All & $34.93(0)$ & $3.03(0.1)$ & $267(3.3)$ & & $55(4)$ & 18.6 & $15.5-19.1$ & $1.20(0.1)$ & 12.8 & $0.86(0.03)$ & 2 \\
\hline & & 2008 & $2500-2600$ & All & $34.93(0)$ & $3(0.1)$ & $250-270$ & & $\begin{array}{l}51.8- \\
73.5\end{array}$ & $18-21.7$ & $16.4-29$ & $1.02-1.31$ & $11.8-14.4$ & $0.66-0.86$ & 6 \\
\hline & & 1996 & $2500-2600$ & All & $34.95(0)$ & $3.12(0.1)$ & $262(2.6)$ & & $60.7(3)$ & $18.5(0.2)$ & $22.4(1.2)$ & $1.26(0.02)$ & $12.4(0.2)$ & $0.89(0.01)$ & 6 \\
\hline \multirow{3}{*}{$\begin{array}{l}\text { NEADW } \\
\text {-upper }\end{array}$} & NROCK & 2010 & $2500-2600$ & All & $34.93(0)$ & $2.96(0.1)$ & 249-267 & & $\begin{array}{l}54.7- \\
75.4\end{array}$ & $17.8-21.5$ & $18.5-32.8$ & $1.16-1.35$ & $12.3-13.9$ & $0.82-0.88$ & 1 \\
\hline & & 2009 & $2500-2600$ & All & $34.92(0)$ & $3.04(0.1)$ & $255-267$ & & $\begin{array}{l}54.1- \\
69.5\end{array}$ & $17.8-18.9$ & $17.8-27.9$ & $1.06-1.13$ & $12.0-12.4$ & $0.7-0.93$ & 2 \\
\hline & & 1996 & $2500-2600$ & All & $34.94(0)$ & $3.02(0.1)$ & $248-261$ & & $\begin{array}{l}60.3- \\
76.5 \\
\end{array}$ & $18.2-20.3$ & $21.2-33.5$ & $1.26-1.39$ & $12.1-12.7$ & $0.86-0.92$ & 6 \\
\hline \multirow{4}{*}{$\begin{array}{l}\text { NEADW } \\
\text {-lower }\end{array}$} & SROCK & 2010 & $2900-3000$ & All & $34.92(0.01)$ & $2.56(0.1)$ & 260 & & 72.1 & & 30.9 & 1.29 & 18.5 & 0.85 & 1 \\
\hline & & 2009 & $2900-3000$ & All & $34.92(0.01)$ & $2.67(0.1)$ & $252(2)$ & & $73.3(2.5)$ & $20.8(0.8)$ & $30.9(2.5)$ & $1.31(0.1)$ & $13.5(0.5)$ & $0.86(0.1)$ & 2 \\
\hline & & 2008 & $2900-3000$ & All & $34.92(0.01)$ & $2.65(0.2)$ & $246(2.6)$ & & $79.8(3.3)$ & $21(0.04)$ & $34(2)$ & $1.07(0.01)$ & $13.0(0.4)$ & $0.58(0.01)$ & 3 \\
\hline & & 1996 & $2900-3000$ & All & $34.94(0)$ & $2.76(0.1)$ & 247 (3.4) & & $78.6(4.4)$ & $20.8(0.6)$ & $31.9-40$ & $1.43(0.1)$ & $12.9(0.2)$ & $0.94(0.02)$ & 4 \\
\hline \multirow{3}{*}{$\begin{array}{l}\text { NEADW } \\
\text {-lower }\end{array}$} & NROCK & 2010 & $>2800$ & All & $34.92(0)$ & $2.68(0.1)$ & $250(2.1)$ & & $75.1(2.1)$ & $20.8(0.2)$ & $33.3(1.2)$ & $1.38(0.03)$ & $13.3(0)$ & $0.92(0.04)$ & 2 \\
\hline & & 2009 & $>2800$ & All & $34.92(0)$ & $2.71(0.04)$ & $250(2)$ & & $74.8(2.3)$ & $19.8(0.5)$ & $32.7(0.5)$ & $1.33(0.08)$ & $12.3(0.7)$ & $0.88(0.1)$ & 2 \\
\hline & & 1996 & $>2800$ & All & $34.94(0)$ & $2.77(0.1)$ & $247(1.2)$ & & $78(1.4)$ & $20.5(0.2)$ & $34.8(1.3)$ & $1.4(0.02)$ & $12.7(0.1)$ & $0.92(0.01)$ & 6 \\
\hline \multirow[t]{4}{*}{ AABW } & SROCK & 2010 & $>2990$ & $65-67$ & $34.92(0.01)$ & $2.55(0.1)$ & $243(0.7)$ & & $84.2(0.8)$ & $22(0.2)$ & $41.3(0.5)$ & $1.46(0.02)$ & 13.7 & 0.93 & 3 \\
\hline & & 2009 & $>2990$ & 12 & $34.91(0.01)$ & $2.51(0.03)$ & 245 & & 82.1 & 21.6 & 40.5 & 1.43 & 13.4 & 0.93 & 1 \\
\hline & & 2008 & $>2990$ & 15 & $34.91(0.01)$ & $2.52(0.1)$ & 237 & & 90.4 & 22.7 & 41.7 & 1.25 & 13.6 & 0.70 & 1 \\
\hline & & 1996 & $>3000$ & $142-143$ & $34.93(0.01)$ & $2.6(0.1)$ & $241(0.1)$ & & $85.9(0.1)$ & $22(0.1)$ & $42(0.4)$ & $1.51(0.01)$ & $13.4(0.1)$ & $0.98(0.01)$ & 2 \\
\hline
\end{tabular}

